\title{
$\begin{array}{llllllll}\mathbf{A} & \mathbf{R} & \mathbf{T} & \mathbf{Y} & \mathbf{K} & \mathbf{U} & \mathbf{L} & \mathbf{Y}\end{array}$
}

Collectanea Theologica

88(2018) nr 3

\author{
ADAM KUBIŚ, LUBLIN
}

\section{TEMAT STWORZENIA W EWANGELII JANOWEJ}

W Listach św. Pawła występuje idea nowego stworzenia wyrażona

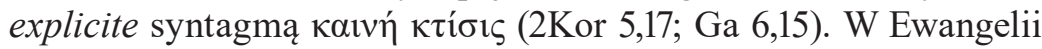
św. Jana nie występuje co prawda powyższe wyrażenie, ale idea stworzenia rozumiana także jako odnowienie stworzenia czy też ponowne stworzenie jest również obecna. Jest ona jednak bardziej zawoalowana, gdyż ukryta w aluzjach niejednokrotnie trudnych do zidentyfikowania. Wśród wczesnochrześcijańskich pisarzy naturalne było odczytywanie aluzji do tematu stworzenia w czwartej Ewangelii. Ojcowie Kościoła pozostawili zatem bogatą spuściznę w identyfikowaniu Janowych aluzji do Rdz 1-3. Ciekawe, że w czasach nowożytnych dopiero brytyjski uczony, sir Edwin Clement Hoskyns, w artykule z 1920 r., zwrócił uwagę współczesnych czytelników czwartej Ewangelii na bogatą symbolikę stworzenia obecną w narracji o męce Jezusa i Jego zmartwychwstaniu. ${ }^{1}$ Po prawie stu latach od pionierskiego artykułu Hoskynsa powstało wiele znaczących artykułów oraz przynajmniej dwie monografie omawiające aluzje do Rdz 1-3 nie tylko w J 19-20, ale w całej Ewangelii. ${ }^{2}$ W języku polskim temat ten wciąż jednak nie doczekał się całościowego i pogłębionego opracowania. Istnieje tylko jeden, niezwykle oryginalny w swych tezach, artykuł ks. Mariusza Rosika dotyczący motywów edenicznych

1 E. C. H o s k y n s, Genesis I-III and St John's Gospel, The Journal of Theological Studies 21/1920, s. 210-218.

2 A. M. M o o r e, Signs of Salvation. The Theme of Creation in John's Gospel, Cambridge 2013; C. R. S o s a S i 1 i e z a r, Creation Imagery in the Gospel of John, LNTS 546, London 2015. Wspomnieć należy także o nieopublikowanej pracy T. C. V o o r $\mathrm{t}$ m a n, Understanding the Fourth Gospel from the Perspective of the Creation Theme (praca doktorska, Rand Afrikaans University, 1998). 
w J 20,1-18. ${ }^{3}$ Niniejszy artykuł chce zatem wypełnić istniejącą lukę w polskim piśmiennictwie biblijno-teologicznym. Powyżej zasygnalizowany brak oraz ograniczone ramy artykułu narzucają niniejszemu opracowaniu charakter introdukcyjny i przeglądowy. Z konieczności zatem, celem artykułu nie jest ujęcie wyczerpujące, które dogłębnie analizowałoby każdy motyw stworzenia występujący na kartach Ewangelii Janowej. Opracowanie ma raczej stanowić przewodnik sygnalizujący bogactwo i wielorakość aluzji do tematu stworzenia w tekście czwartej Ewangelii.

Z braku oznaczonych cytatów z Rdz 1-3 w narracji Janowej, ograniczymy się do aluzji, pomijając poza nielicznymi wyjątkami fenomen intertekstualny zwany echem. ${ }^{4}$ Szukając principiów metodologicznych dla poniższej prezentacji, należy wskazać na cztery podstawowe kryteria identyfikowania aluzji do Rdz 1-3 w tekście Janowej Ewangelii. Pierwszym będzie podobieństwo między hypo-tekstem ( $\mathrm{Rdz}$

3 M. R o s i k, Interpretacja Janowej narracji o otwartym grobie (J 20,1-18) $w$ świetle mitu o rajskim ogrodzie, Collectanea Theologica 71 (2004) nr 1, s. 39-63. Ks. Mirosław $Ł$ a n o s z k a w swych dwóch pracach koncentruje się jedynie na tradycji synoptycznej oraz $1 \mathrm{~J}$ 2,17 i Ap 21,1-5; zob. t e n ż e, Idea odnowienia kosmosu jako obraz nadchodzacej petni królestwa Bożego, Tarnowskie Studia Teologiczne 25(2006) nr 2, s. 39-60; t e n ż e, Idea odnowienia kosmosu w eschatologicznej doktrynie synoptycznej i Janowej, W kręgu Słowa 4, Tarnów 2009. Poniższe dwa artykuły nie omawiają tekstów z czwartej Ewangelii: S. W y p y c h, ,,Nowe niebiosa i nowa ziemia”. Rozwój biblijnej idei ,nowego stworzenia”, Analecta Cracoviensia 3/1971, s. 221-234; J. K o z y r a, Nowe stworzenie - kaine ktisis, Śląskie Studia Historyczno-Teologiczne 11/1978, s. 13-40.

4 C. R. S o s a S i 1 i e z a r, Creation, s. 11, rezygnuje z mówienia o aluzji i echu, używając pojęcia creation imagery. Powodem jest symboliczna i sensoryczna (zmysłowa) natura Janowej Ewangelii, która implikuje opisowy i figuratywny język. W naszym przekonaniu, podział na aluzję i echo, odwołujący się do zdolności słuchacza/czytelnika do przełożenia odkrytego odniesienia do hypo-tekstu ( $\operatorname{Rdz} 1-3)$ na nową interpretację hiper-textu (J), jest wciąż użyteczny. Jeśli hypo-tekst wpływa na interpretację hyper-tekstu mówimy o fenomenie zwanym aluzją. Jeśli tego wpływu nie ma, mamy do czynienia z echem. Więcej na temat metodologicznych kwestii związanych z badaniami intertekstualnymi czwartej Ewangelii; zob. A. K u b i ś, Drzewo figowe, osiot $i$ woda żywa. Rola Księgi Zachariasza w Ewangelii Janowej, Resovia Sacra 22/2015, s. 212-237, zwł. s. 217-220. 
1-3) a hyper-tekstem (Ewangelia Janowa) na poziomie terminologii (nawet pojedynczego słowa), składni, obrazu, tematu, kontekstu. Drugim będzie kryterium nieciągłości gramatycznej, jak i narracyjnej (logicznej). Trzecim jest Janowe principium double entendre, rozumiane jako zamierzona dwuznaczność wielu terminów czy wyrażeń Janowych. ${ }^{5}$ Czwartym kryterium będzie historia interpretacji, gdyż wiele aluzji zostało zidentyfikowanych już w starożytności i na trwałe zapisało się w historii egzegezy danego tekstu Janowego. W odkrywaniu obecności aluzji będziemy się odwoływać do ustaleń starożytnych i współczesnych egzegetów. ${ }^{6}$ Niniejsza prezentacja zawierać będzie jednak tylko wybór aluzji, nie roszcząc sobie prawa do bycia wyczerpującym kompendium wszystkich, powstałych na przestrzeni wieków, propozycji. W identyfikacji aluzji nieodzowna jest właściwa doza krytycyzmu, gdyż bardzo wiele propozycji, bazując na kruchych podstawach metodologicznych, ma znamiona nieuprawnionej nadinterpretacji. Propozycje wybitnie hipotetyczne zostały pominięte. ${ }^{7}$ Niejasność w aplikowaniu kryteriów identyfikacji

5 Zob. G. van B e $11 \mathrm{e}$, Double Entendre in the Gospel according to John, w: G. van B e 11 e, J. G. van der W a t t, P. M a r i t z (red.), Theology and Christology in the Fourth Gospel. Essays by the Members of the SNTS Johannine Writings Seminar, BETL 184; Leuven 2005, s. 463-481; E. R i c h a r d, Expressions of Double Meaning and Their Function in the Gospel of John, New Testament Studies 31/1985, s. 69-112.

${ }^{6} \quad$ Więcej na temat powyższych i innych kryteriów pomocnych w identyfikacji aluzji zob. R. B. H a y s, Echoes of Scripture in the Letters of Paul, New Haven, CT 1989, s. 29-32; t e $\mathrm{n} \dot{\mathrm{z}}$ e, The Conversation of the Imagination. Paul as Interpreter of Israel's Scripture, Grand Rapids 2005, s. 34-45; M. T h o m p s o n, Clothed with Christ. The Example and Teaching of Jesus in Romans 12.1 - 15.13, JSNT.S 59, Sheffield 1991, s. 31-36.

7 Odnośnie do subiektywności procesu odkrywania i analizy odniesień intertekstualnych zob. A. K u b i ś, Drzewo figowe, s. 220: „Niektórzy czytelnicy (zależnie od swoich kompetencji, wiedzy, wrażliwości itp.) będą w stanie dostrzec aluzję, inni będą widzieć tylko echo, jeszcze inni nie zobaczą w danym tekście żadnego odniesienia do Starego Testamentu. Stąd, chcąc zbliżyć się do obiektywizmu (do prawdy), należy poddać pod naukową debatę swoje odkrycie/interpretację/identyfikację aluzji czy echa. Głównym problemem zatem jest nie tyle sposób odkrywania 
aluzji i echa sprawiła, że nie istnieje opinio communis odnośnie do liczby intertekstualnych odniesień do Rdz 1-3 w czwartej Ewangelii, a co za tym idzie również brak jest konsensusu co do ważności tychże odniesień w interpretacji narracji Janowej. Jednomyślność panuje jedynie w uznaniu obecności tematu stworzenia w czwartej Ewangelii jako takiej, ze wskazaniem na prolog, Modlitwę Arcykapłańską oraz J 20,22.

Prezentacja poszczególnych aluzji w niniejszym artykule została usystematyzowana według klucza narzuconego przez strukturę samej Ewangelii. Wpierw omówiono zatem odniesienia do Rdz 1-3 występujące w Prologu Janowym (1,1-18), następnie zaś te obecne w Księdze Znaków (1,19-12,50), a na końcu - w Księdze Chwały (12,1-21,25).

\section{Prolog}

Poczynając od Orygenesa (Comm. Jo. 2,36), liczni komentatorzy od starożytności po współczesność - pierwsze słowa Ewangelii Jana, $\dot{\varepsilon} v$ ả $\rho \chi \tilde{n}$, traktują jako aluzję do pierwszego zdania Księgi Rodzaju w przekładzie Septuaginty. Zarówno w Rdz 1,1, jak i w J 1,1, غ̇v ả $\rho \tilde{n}$ nie tylko rozpoczyna zdanie, ale także otwiera całą księgę. $\mathrm{W}$ obu przypadkach mówi narrator, w obu zdaniach tematem jest początek dziejów świata. Oba zdania zdradzają podobieństwo dźwięku oraz

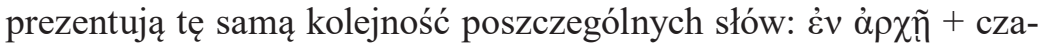

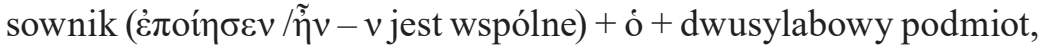
z dwoma samogłoskami, kończący się na - os $(\theta \varepsilon o ́ \varsigma / \lambda o ́ \gamma o \varsigma){ }^{8}$

W prologu obecne są także inne aluzje do Rdz 1-3. Temat stworzenia świata obecny jest wprost w 1,3 oraz 1,10. Tematy światła ( $\varphi \tilde{\omega} \varsigma)$ i ciemności ( $\sigma \kappa o \tau i ́ \alpha)$ ) występujące w prologu Ewangelii $(1,4-5)$ obecne są również w opisie stworzenia w Rdz 1 (w. 2-5.14-18). Kluczowy dla

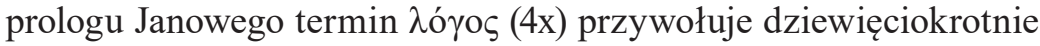

aluzji (kryteriów służących jej identyfikacji może być wiele), ale raczej pytanie, czy nasza interpretacja danego tekstu jest wiarygodna".

8 Za: D. C. A 11 is o n, The New Moses. A Matthean Typology, Edinburgh 1993, s. 20. 
powtarzane w opisie stworzenia w Rdz 1 wyrażenie „Bóg powiedział” ( $\varepsilon \tilde{i} \pi \varepsilon v$ ó $\theta \varepsilon o ́ \varsigma)$. Intuicja ta wydaje się właściwa, gdyż obraz Boga

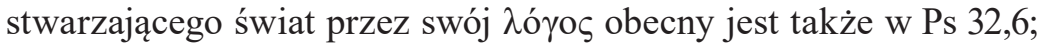
Mdr 9,1; Targumie Neofiti do Rdz 1,1- 2,2 i w wielu starożytnych pozabiblijnych tekstach chrześcijańskich i żydowskich. ${ }^{9}$ Słowa

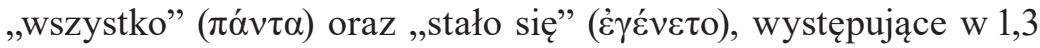
(czasownik trzykrotnie), są wielokrotnie obecne w Rdz 1,1 - 2,7. Już Jan Chryzostom (Hom. Jo. 5,1) wskazał na Janowe stwierdzenie, że wszystko się stało za sprawą Boskiego $\lambda$ ó $o \varsigma(1,3)$, jako na aluzję do idei stworzenia wszystkiego przez Boga z Rdz 1-2. Motyw życia

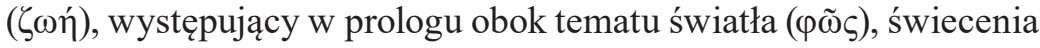

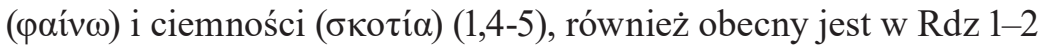

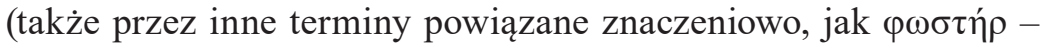
„gwiazda” czy $\varphi \alpha \tilde{\sigma} \sigma \varsigma \varsigma_{-}$,światłość”). W prologu występuje także

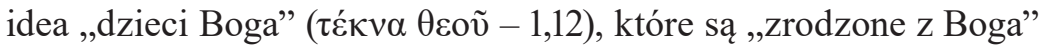

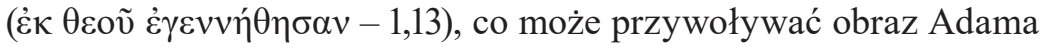
i Ewy, pochodzących bezpośrednio od Boga. Juana Mateos i Juana Barreto twierdzą, że cały zestaw terminów związanych z życiem,

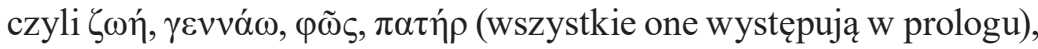

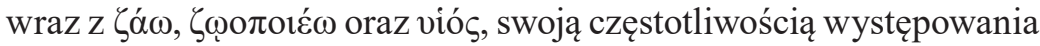
w Ewangelii Jana przewyższa inne Ewangelie kanoniczne oraz ma za swe tło interpretacyjne idę̨ stworzenia; ${ }^{10}$ John McHugh uważa, że trójczłonowa struktura zdania w J 1,10 odpowiada logice narra-

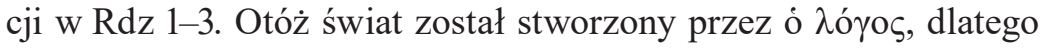
jest dobry (Rdz 1). ó $\lambda$ ó yos było na świecie, dlatego wezwało świat

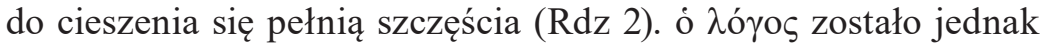

9 Całą ich listę przedstawia M. E n d o, Creation and Christology. A Study on the Johannine Prologue in the Light of Early Jewish Creation Accounts, WUNT 2/149, Tübingen 2002, s. 210.

10 J. M a t e o s, J. B a r r e t o, Dizionario teologico del Vangelo di Giovanni, Assisi 1982, s. 56-57. Do tego spisu należałoby także dodać typowo Janowy (nie-

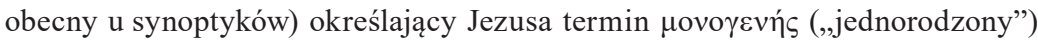
$(1,14.18 ; 3,16.18)$. 
odrzucone (Rdz 3). ${ }^{11}$ Paul S. Minear sugeruje nadto, że wyrażenie

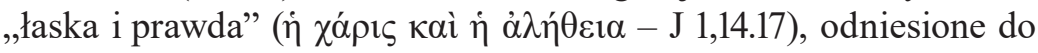
Jezusa, wskazuje na Jego misję otwarcia drogi do sytuacji opisanej w Rdz 1-2. Potrójna negacja obecna w J 1,13 (,,ani z krwi, ani z żądzy ciała, ani z woli męża") jest aluzją do usunięcia przekleństwa złożonego na kobietę w Rdz 3,16. ${ }^{12}$ Mary Coloe uważa również, że struktura J 1,1-18 nawiązuje do struktury Rdz 1,1-2,4a. Podczas gdy opis z Rdz 1 kończy się kulminacyjnym dniem siódmym, w którym Bóg dokończył swego dzieła stworzenia, struktura prologu Janowego pozbawiona jest tego punktu kulminacyjnego, wskazując na dzieło Jezusa opisane w dalszej części Ewangelii jako na dzieło dokończenia dzieła Ojca. ${ }^{13}$

Znamienne jest tematyczne inclusio związane z życiem, obecne w Ewangelii Janowej. Na początku narracji stwierdza się, że Jezus jest życiem (1,4; zob. 14,6); podczas gdy na jej końcu pada stwierdzenie, że celem, dla którego została napisana Ewangeli, jest budzenie wiary dającej właśnie życie (20,31; zob. 3,15.16). Nadto, idea życia

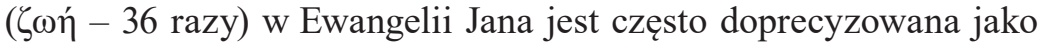

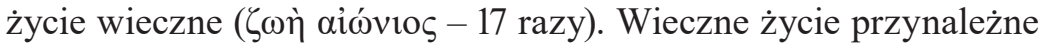
jest jedynie Bogu i tym, którzy są z Bogiem zjednoczeni przez wiarę. Jednocześnie w teologii Janowej idea życia powiązana jest ze zmartwychwstaniem (zob. 11,25). Co istotne, w judaizmie czasów Jezusa idea zmartwychwstania i odnowy stworzenia były ze sobą nierozerwalnie powiązane. W eschatologii ówczesnego judaizmu oczekiwano bowiem powszechnego zmartwychwstania i powiązanej z nim odnowy całego stworzenia. ${ }^{14} \mathrm{~W}$ teologii Janowej zmartwychwstały

11 J. F. M c H u g h, A Critical and Exegetical Commentary on John 1-4, The International Critical Commentary, London 2009, s. 40-41.

12 P. S. M i n e a r, Christians and the New Creation. Genesis Motifs in the New Testament, Louisville 1994, s. 83-85, 92-93, 100.

13 M. C o 1 o e, The Structure of the Johannine Prologue and Genesis 1, Australian Biblical Review 45/1997, s. 52-54. Krytyka tego ujęcia: C. R. S o s a S i 1 i e z a r, Creation, s. 42-43.

14 G. K. B e a 1 e, The Eschatological Conception of New Testament Theology, w: K. E. B r o w e r, M. W. E 11 i o t t (red.), Eschatology in Bible and Theology. 
Jezus ma życie wieczne, które mogą także posiąść wierzący w Niego. W tym sensie, każdy wierzący w Jezusa, otrzymując życie wieczne, doświadcza jednocześnie odnowy stworzenia. ${ }^{15}$

Zdaniem Carlosa R. Sosa Siliezara, tematyka stworzenia w Janowym prologu użyta jest na trzy różne sposoby. Po pierwsze, Jan opisuje ó $\lambda o ́ \gamma o s$ jako będący w ścisłej relacji z Bogiem, istniejący przed światem stworzonym i uczestniczący w działaniu Boga. Po drugie, odniesienia do stworzenia wskazują na podstawowe i uniwersalne znaczenie ó $\lambda$ ó $o s$, które przekracza znaczenie Jana Chrzciciela i Mojżesza. Po trzecie, Jan, odnosząc się do idei stworzenia, łączy przeszłość z teraźniejszością i przyszłością, gdyż Słowo dokonało dzieła stworzenia, ale obecnie dokonuje dzieła objawienia i zbawienia. ${ }^{16}$

Bez wątpienia istotne jest samo umiejscowienie tematu stworzenia w globalnym planie całej Ewangelii. Jan, rozpoczynając swą narrację nawiązaniem do opisu stworzenia z Rdz 1-3, wskazuje klucz do lektury wydarzenia Jezusa. Innymi słowy, Janowa opowieść o Jezusie winna być czytana $\mathrm{w}$ perspektywie tematu stworzenia. ${ }^{17}$ Obok tematu Paschy-przymierza jest to, jak się wydaje, druga najważniejsza oś tematyczna całej Ewangelii. ${ }^{18}$ Rozpoczynając Ewangelię w sposób, w jaki rozpoczyna się pierwsza księga Tory i całej Biblii,

Evangelical Essays at the Dawn of a New Millennium, Downers Grove (IL) 1997, s. 19: „New creation is in mind whenever the concept of resurrection occurs, since it is essentially the new creation of humanity".

15 Więcej na temat Janowej koncepcji życia jako motywu odnowionego stworzenia w J. K. B r o w n, Creation's Renewal in the Gospel of John, Catholic Biblical Quarterly 72/2010, s. 277-278.

16 C. R. S o s a S i 1 i e z a r, Creation, s. 42-43.

17 J. K. B r o w n, Creation's Renewal, s. 277. Autorka mówi o „centrality of creation as the context from which he [John] will tell his story of Jesus". T. C. Vo o r t m a n, Understanding, s. 1, twierdzi, że należy czytać Ewangelię Janową „,with the creation theme constantly in mind".

18 J. M a t e o s, J. B a r r e t o, Dizionario, s. 56: „Questa della creazione è una delle due linee portanti della teologia del vangelo di Gv; la seconda è quella della Pasqua-alleanza". 
Jan najprawdopodobniej sugeruje swym adresatom, że jego dzieło będzie nową Torą lub nawet nową Biblią. ${ }^{19}$

\section{Księga Znaków}

\section{Struktura}

Niektórzy egzegeci widzą w pierwszych scenach Ewangelii (1,192,11) schemat siedmiu dni, który w efekcie miałby nawiązywać do pierwszego tygodnia stworzenia z Rdz 1-2: dzień 1: świadectwo Jana Chrzciciela (1,19-28); dzień 2: „Oto Baranek Boży” (1,29-34); dzień 3: powołanie Andrzeja i jego towarzysza (1,35-39); dzień 4: powołanie Szymona Piotra (1,40-42); dzień 5: powołanie Filipa (1,43-46); dzień 6: powołanie Natanaela (1,47-51); dzień 7: gody weselne w Kanie (2,1-11). ${ }^{20}$ Podział powyższy nie jest jedynym jaki proponują egzegeci, gdyż w samym tekście Ewangelii nie ma wystarczająco jasnych odniesień pozwalających na jednoznaczne wyróżnienie siedmiu dni. Trzymając się ściśle tekstu, mowa jest co najwyżej o sześciu dniach. $\mathrm{Z}$ tego powodu, W. F. Hambly czy L. Paul Trudinger twierdzą, że 2,12 mówi o siódmym dniu, rozumianym jako dzień Jezusowego odpoczynku (szabatu) po dokonaniu cudu w Kanie. ${ }^{21}$ Pojawiły się jednak nieprzekonujące próby traktowania prologu jako opisu pierwszego

19 Powyższa teza za M. J. J. M e n k e n, Genesis in John's Gospel and 1 John, w: S. M o y i s e, M. J. J. M e n k e n (red.), Genesis in the New Testament, LNT 466, London 2012, s. 89.

20 E.-B. A 11 o, L'Évangile sprituel de saint Jean suivi de le Règne de Dieu et le Monde, Paris 1944, s. 75-76; F. Q u i é v r e u x, La structure symbolique de l'Évangile de Saint Jean, Revue d'histoire et de philosophie religieuses 33(1953) nr 2, s. 123-165; T. B a r r o s s e, The Seven Days of the New Creation in St. John's Gospel, Catholic Biblical Quarterly 21/1959, s. 507-516.

${ }_{21}$ Zob. W. F. H a m b 1 y, Creation and Gospel. A Brief Comparison of Genesis 1,1-2,4 and John 1,1-2,12, w: F. L. C r o s s (red.), Studia Evangelica. V. Papers Presented to the Third International Congress on the New Testament Studies Held at Christ Church, Oxford, 1965, Berlin 1968, s. 69-74; L.P. T r u d n i g e r, The Seven Days of the New Creation in St. John's Gospel: Some Further Reflections, Evangelical Quarterly 44/1972, s. 154-159. 
dnia nowego stworzenia ${ }^{22}$ czy też umiejscawiania opisu cudu w Kanie w ósmym dniu. ${ }^{23}$ Podczas gdy próby widzenia w 1,19 - 2,12 siedmiu dni stworzenia są nieprzekonujące, obecny w tekście schemat sześciu dni wydaje się usprawiedliwionym kluczem interpretacyjnym.

Nie brak także propozycji, które starają się dostrzec w całej czwartej Ewangelii symboliczną strukturę odwołującą się do siedmiu dni stworzenia. ${ }^{24}$ Dla przykładu, Juan Mateos i Juan Barreto uważają, że szósty dzień rozpoczęty cudem w Kanie trwa aż do momentu śmierci Jezusa, który rzeczywiście umiera w piątek, a zatem szóstego dnia tygodnia. Dzień zmartwychwstania, następujący pierwszego dnia po szabacie, jest pierwszym dniem nowego stworzenia (20,1-31). Cała zatem publiczna działalność Jezusa, od cudu w Kanie aż do momentu Jego śmierci $(2,1-19,42)$, dokonuje się ,pod znakiem” (el signo) „szóstego dnia”. ${ }^{25} \mathrm{~W}$ tym samym symbolicznym kluczu pierwszego

$22 \mathrm{~Np} . \mathrm{J} . \mathrm{W}$ i 11 e m s e, Het vierde evangelie. Eeen onderzoek naar zijn structuur, Hilversum-Anwerpen 1965, s. 151-157.

${ }_{23} \mathrm{~Np}$. P. W. S k e h a n, The Date of the Last Supper, Catholic Biblical Quarterly 20/1958, s. 197-198; P. V a n D i e m e n, La semaine inaugurale et la semaine terminale de l'Évangile de Jean. Message et structures (dysertacja doktorska), Rome 1972, t. 1, s. 63-76 Różne próby podziału czasowego pierwszych dwóch rozdziałów Ewangelii Jana omawia A. S e r r a, Contributi dell'antica letteratura giudaica per l'esegesi di Giovanni 2, 1-12 e 19, 25-27, Scripta Pontificiae Facultatis Theologicae "Marianum" 31, Roma 1977, s. 29-44; H. S a x b y, The Time-Scheme in the Gospel of John, Expository Times 104/1992, s. 9-13. Odnośnie do problemu rozumienia

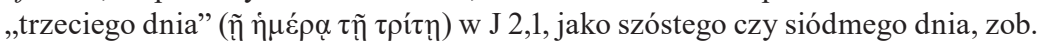
T. E. P h 111 i p s, ,The Third Fifth Day?” John 2:1 in Context, Expository Times 115/2004, s. 328-331. Krytyczne omówienie i odrzucenie tezy o istnieniu odniesienia intertekstualnego między pierwszym tygodniem stworzenia z Rdz 1-2 i pierwszym tygodniem działalności Jezusa w Ewangelii Jana zawiera C. R. S o s a S i 1 i e z a r, Creation, s. 123-130.

24 Istnieje także propozycja ujęcia jedynie J 1-5 w nawiązaniu do siedmiu dni z Rdz 1-2; zob. C. M. C a r $\mathrm{m}$ i c h a e 1, The Story of Creation. Its Origins and Its Interpretation in Philo and the Fourth Gospel, Ithaca 1996, s. 41-126: dzień 1: J 1,15-42; dzień 2: 1,43-51; dzień 3: 2,1-12; dzień 4: 2,13 - 3,21; dzień 5: 3,22-36; dzień 6: 4,1-54; dzień 7: 5,1-47.

25 J. M a t t e o s, J. B a r r e t o, El Evangelio de Juan. Análisis lingüístico y comentario exegético, Lectura del Nuevo Testamento 4, Madrid 1982, s. 15 : 
tygodnia stworzenia, Marie-Émile Boismard, a za nim inni, dzielą Ewangelię Janową na siedem części odpowiadających siedmiu dniom stworzenia, w których pierwsze trzy dni służą oddzieleniu ekonomii nowej od starej, a trzy kolejne ,zaludnieniu” świata przez światło i życie: dzień 1 - dar Ducha (1,29-34) i nowe wino (2,1-11); dzień 2 - nowa świątynia (2,13-21), nowe narodzenie (3,3-21), nowy kult (4,20-24); dzień 3 - nowy szabat Bożego dzieła (J 5) i nowa manna (J 6); dzień 4 - światło świata (J 7-9); dzień 5 - nowe życie (J 10-11); dzień 6 - dojrzewanie nowego człowieka (J 12-19); dzień 7 - nowe stworzenie (J 20). ${ }^{26}$ Propozycje te, mimo swej symbolicznej atrakcyjności,

„El tema de la creación, que se abre en el prologo (1,1ss), domina la cronología y da una clave de interpretación de la obra de Jesús. (...) De ahí que toda actividad de Jesús, hasta su muerte, quede bajo el signo de el día sexto, indicando el disignio que la preside: dar remate a la obra creadora, compltando al hombre con el Espíritu de Dios (cf. 19,30; 20,22)”. „Szósty dzień” charakteryzujący cały okres publicznej działalności Jezusa komentatorzy ci dzielą na „dzień Mesjasza” $(2,1-11,54)$ oraz „ostatnią godzinę” tego szóstego dnia, czyli Paschę Mesjasza (11,55 - 19,42).

26 M.-É. B o i s m a r d, L'évangile à quatre dimensions, Lumière 5(1951) nr 1, s. 94-114; t e n ż e, Le Prologue de Saint Jean, Lectio Divina 11, Paris 1953, s. 137-138. Zob. M. G i r a r d, La structure heptapartite du quatrième évangile, Sciences Religieuses 5/1975-1976, s. 350-359; J. G o e $t$ t $m$ a n n, Saint Jean. Évangile de la Nouvelle Genèse, Paris 1982. W swym późniejszym komentarzu M.-É. Boismard modyfikuje swoją propozycję, mówiąc o strukturze ośmiu „tygodni”, poprzedzonych wstępem (1,1-18) i zakończonych epilogiem (21,1-25). Na każdy symboliczny „tydzień” składa się święto i znak: tydzień 1: bez święta, znak w Kanie $(1,19-2,12)$; tydzień 2: pierwsza Pascha i uzdrowienie dziecka w Kafarnaum $(2,13$ - 4,54); tydzień 3: druga Pascha i rozmnożenie chleba (6,1-71); tydzień 4: Pięćdziesiątnica i uzdrowienie paralityka (5,1-47); tydzień 5: Święto Namiotów i uzdrowienie niewidomego $(7,1-10,21)$; tydzień 6: Święto Poświęcenia Świątyni i wskrzeszenie Łazarza (10,22 - 11,54); tydzień 7: trzecia Pascha i brak znaku (11,55 - 19,42); tydzień 8: brak święta i znak zmartwychwstania Jezusa (20,1-31). W siódmym tygodniu Jezus nie pracuje, a zatem nie dokonuje znaku, gdyż tydzień ten ma odpowiadać spoczynkowi szabatowemu. Znak chodzenia po wodzie jest jedynie efektem przeniesienia pewnych elementów chrystofanii z J 20-21 do J 6, w celu upodobnienia narracji do synoptyków; zob. M.-É. B o i s m a r d, A. L a m o u i 11 e, L'évangile de Jean, Synopse des quatre Évangiles en français 3, Paris 1977, s. 39, 44. 
nie zyskały uznania egzegetów. Głównym zarzutem jest sztuczne podporządkowanie tekstu do założonej tezy. ${ }^{27}$

\section{Znaki i dzieła Jezusa}

Liczba siedmiu znaków występująca w Księdze Znaków jest widziana przez niektórych egzegetów jako nawiązanie do siedmiu dni stworzenia z Rdz 1-2. Znakami tymi są: 1 . zmiana wody w wino (2,1-11); 2. uzdrowienie syna urzędnika (4,46-54); 3. uzdrowienie chromego (5,1-9); 4. nakarmienie pięciu tysięcy $(6,1-15)$; 5 . chodzenie po wodzie (6,16-21); 6. uzdrowienie niewidomego (9,1-7); 7. wskrzeszenie Łazarza (11,1-44). Zmartwychwstanie Jezusa winno być postrzegane

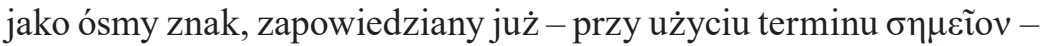
W narracji o oczyszczeniu świątyni $(2,18-19) \cdot{ }^{28}$ Próby powiązania każdego z powyższych znaków z kolejnym dniem stworzenia nie są jednak przekonujące. ${ }^{29}$

27 Przekonującą krytykę ujęcia opartego na sześciu dniach przedstawia G. M 1 a k u z h y i 1, The Christocentric Literary Structure of the Fourth Gospel. Second Enlarged Edition, Analecta biblica 117, Rome 2011, s. 74-75. Ten sam autor (s. 80-81) prezentuje również krytyczne porównanie obu struktur M.-É. Boismarda.

${ }^{28}$ Kwestia liczby znaków jest również dyskutowana, gdyż wskazuje się jako

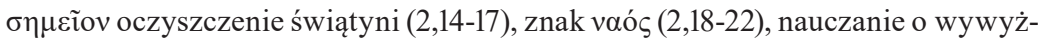
szeniu węża na pustyni (3,14-15), namaszczenie Jezusa $(12,1-8)$, triumfalny wjazd do Jerozolimy (12,12-16), umycie nóg (13,1-20), chrystofanie $(20,1-29)$ oraz cudowny połów (21,1-14). Zob. rozdział Discussione sul numero dei segni w: G. B i g u z z i, Il vangelo dei segni, Studi biblici 175, Brescia 2014, s. 62-78.

29 Spośród autorów opowiadających się za istnieniem w Janowej liczbie siedmiu znaków odwołania do siedmiu dni stworzenia należy wymienić: D. A. Carson, F. J. Moloney, M. Rae (2008), J. K. Brown, M. Coloe, A. M. Moore. Odwołania bibliograficzne do prac wymienionych egzegetów wraz z przekonującą krytyką ich tezy przedstawił C. R. S o s a S i 1 i e z a r, Creation, s. 130-141. Dla przykładu, A. M. Moore przekonuje, że w każdym z siedmiu powyższych znaków, a także w opisie cudownego połowu $(21,1-14)$ występuje wysoki procent słownictwa wskazującego na obecność tematu stworzenia (creation indicators). Do słów takich

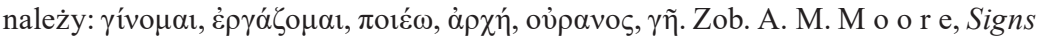
of Salvation, s. 94-130. Słowa te jednak mają zbyt ogólne znaczenia, aby wiązać je ekskluzywnie z tematem stworzenia. 
W wielu miejscach czwartej Ewangelii Jezus jest przedstawiony jako dokonujący „dzieł” ( $\tau$ ò ě $\rho \gamma \alpha) \cdot{ }^{30}$ Dzieła Jezusa $(10,38)$ są charakteryzowane jako dzieła Ojca (4,34; 5,36; 9,3-4; 10,25.32.37), gdyż Ojciec jest w Jezusie, a Jezus w Ojcu $(10,38 ; 14,10.11$; por. 10,30). Ostatecznie to sam Ojciec dokonuje swoich dzieł przez Jezusa $(14,10)$. Dzieł tych dokonają także uczniowie $(14,12)$, na mocy zamieszkiwania w nich Ojca, Syna i Ducha Parakleta. Szczególnie w trzech tekstach, a mianowicie 4,34; 5,36 oraz 10,32, widoczne jest słownictwo

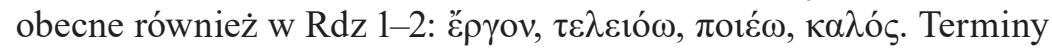
te używane są także do opisu stworzenia w pozabiblijnej literaturze żydowskiej okresu Drugiej Świątyni. ${ }^{31}$ Carlos R. Sosa Siliezar, po przeprowadzeniu szczegółowych analiz porównawczych, stwierdza brak bezpośredniego użycia Rdz 1-2 w Janowym obrazie Jezusa dokonującego czynów swego Ojca. Z drugiej jednak strony mówi on o Janowym kreatywnym użyciu terminów, obrazów i koncepcji wziętych z Rdz 1-2 w opisie Jezusowych dzieł Ojca. ${ }^{32}$ Odwołując się do kryterium historii interpretacji, należy jednak podkreślić fakt, że już w najwcześniejszej tradycji interpretacyjnej widziano w Janowych tekstach o czynach Jezusa dokonującego dzieł Ojca odniesienie do dzieła stworzenia. Dla przykładu, Ireneusz (Hear. 5,15,2) oraz Jan Chryzostom (Hom. Jo. 56,2) odnoszą do dzieła stworzenia $\tau$ ò

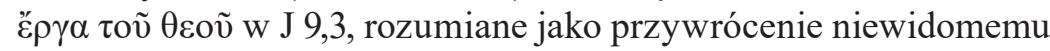
wzroku. Tertulian (Marc. 2,5) odnosi dzieła ( $\tau \grave{\alpha}$ ย̌ $\rho \gamma \alpha$ ) Jezusa w J 10,25 do dobroci dzieł Boga Stworzyciela. Atanazy (C. Ar. 2,15-16) odnosi J 5,17 do prologu Janowego, stwierdzając, że Słowo Boga dokonuje dzieł Boga Stworzyciela. Efrem (Comm. Diat. 13,4) opisuje Jezusa w J 5,17 jako stworzyciela. Powyższy fakt usprawiedliwia zatem szukanie odwołań do tematu stworzenia w opisie poszczególnych

30 Zob. 4,34; 5,20.36; 7,3.21; 9,3-4; 10,25.32-33.37-38; 14,10-12; 15,24; 17,4.

31 Liczne przykłady przytacza C. R. S o s a S i 1 i e z a r, Creation, s. 78-82.

32 Tamże, s. 84. Więcej na temat Janowej koncepcji dzieł Ojca i Jezusa zob. A. K u b i ś, Janowe rozumienie pracy Boga i człowieka. Studium zastosowania

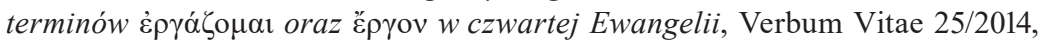
s. $127-154$. 
Janowych znaków. Najbardziej przekonujące próby poszukiwań takich intertekstualnych zależności spotykamy w przypadku czterech z nich: cudu w Kanie, uzdrowienia paralityka, chodzenia Jezusa po wodzie oraz uzdrowienia niewidomego od urodzenia.

Pierwszy znak, Kana, przez obfitość wina przywodzi na myśl zapowiadane i oczekiwane w Starym Testamencie odnowienie Izraela w erze eschatologicznej (np. Am 9,11-13). Odnowa ta rozumiana jest jako odnowa stworzenia. Samo przekraczanie naturalnych i fizycznych praw mające miejsce w przemianie wody w wino może być widziane jako przywołanie obrazu Boga Stwórcy z Rdz $1 .{ }^{33}$ Wyrażenie

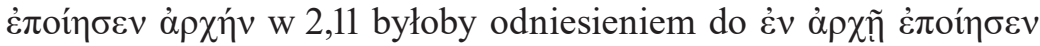
w Rdz 1,1. Sześć stągwi kamiennych miałoby nawiązywać do sześciu dni, w których Bóg dokonał stworzenia (Rdz 2,2 LXX). Woda zgromadzona $\mathrm{w}$ tych naczyniach, zamieniona $\mathrm{w}$ wino, byłaby znakiem odnowionego stworzenia. ${ }^{34}$ Maryja, nazywana w Kanie „kobietą”, ma przywoływać Ewę z Rdz 1-3. Fakt odbywania się zaślubin w Kanie szóstego dnia pierwszego tygodnia działalności Jezusa miałby wskazywać na szósty dzień pierwszego tygodnia stworzenia, kiedy nastąpiło stworzenie pierwszej pary ludzi. Zaślubiny w Kanie byłyby w istocie symbolem zaślubin Boga-Oblubieńca (w osobie Jezusa, nowego Adama) i Kościoła-Oblubienicy (w osobie Maryi, nowej Ewy), zapowiedzią odnowy przymierza i stworzenia. ${ }^{35}$

W narracji o uzdrowieniu paralityka temat szabatu $(5,9.10 .16 .18)$ oraz wyrażenie ,aż dotąd pracuje” odniesione do Ojca $(5,17)$ bez wątpienia nawiązują do żydowskich dyskusji na temat Bożego odpoczynku opisanego w Rdz 2,2-3. Najwcześniejszymi świadkami tych dyskusji jest tekst przypisany Arystobulowi z Paneas (II w. przed

33 Tak T. C. V o o r t m a n, Understanding, s. 152-153.

34 A. S e r r a, ,Vi erano la sei giare...”. Gv 2,6 alla luce di antiche tradizioni giudaico-cristiane relatie ai ,sei giorni" della creazione, w: t e n ż e, Nato da Donna... (Gal 4,4). Ricerche bibliche su Maria di Nazaret (1989-1992), Roma-Milano 1992, s. 141-188.

35 A. M. M o o r e, Sings of Salvation, s. 135-139, przekonuje, że wzmianka o trzecim dniu w 2,1 winna być rozumiana jako odniesienie do zmartwychwstania i pierwszego dnia nowego stworzenia. 
Chr.), zachowany w jednym z dzieł Euzebiusza z Cezarei (Praep. ev. 13,12.9-16) oraz teksty Filona (Leg. All. 1,1-6; Cher. 87, 90). W ówczesnej myśli teologicznej jedynie Bóg mógł pracować, sądzić i dawać życie w dzień szabatu. ${ }^{36}$ Te trzy prerogatywy zostają przypisane Jezusowi. Jezus działa tak samo, jak działa Ojciec (5,17.19-20). Jezus w istocie wykonuje dzieła Ojca $(5,36)$, również sądzi (5,22.27.29.30), w końcu przywraca życie $(5,21)$, czego konkretnym znakiem jest przywrócenie pełni zdrowia choremu człowiekowi. Nie bez znaczenia jest tutaj semantyka terminu v̛yı́s z 5,6.9.11.14.15 odnoszącego się do idei całości, integralności, pełni. W kontekście tematu życia, nie przez przypadek dalszy dialog nawiązuje do idei zmartwychwstania $(5,21.25 .29)$, życia wiecznego $(5,24)$ oraz tożsamości Jezusa zdefiniowanej jako życie par excellence $(5,26.40)$. Tak jak działanie Boga Ojca odnosi się do wszystkich ludzi, podobnie adresowane jest działanie Jezusa $(5,28)$. W istocie użycie obrazów związanych ze stworzeniem służy podkreśleniu boskiej tożsamości Jezusa, Jego ścisłej jedności z Ojcem (zob. 5,18-21), ale również pokazaniu skutków Jego zbawczego działania, które można nazwać nowym stworzeniem.

Wielu komentatorów w obrazie Jezusa „kroczącego po morzu”

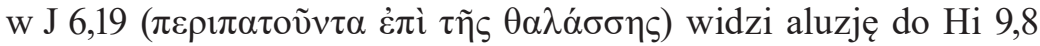
LXX, gdzie mowa jest o Bogu, który „sam rozpina niebiosa i chodzi

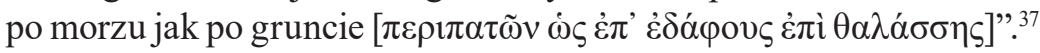
Argumentem za uznaniem tej aluzji jest fakt, że participium „kro-

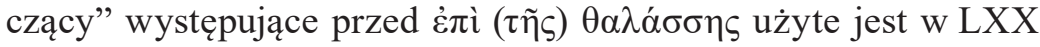
i Nowym Testamencie tylko w Hi 9,8 oraz w opisach Jezusa kroczącego po wodzie (Mt 14,25; Mk 6,48; J 6,19; por. Mt 14,26 i Mk 6,49). Obraz obecny w Hi 9,8 nawiązuje wprost do tematu stworzenia (por. kontekst: Hi 6,5-13). Podobnie powiązanie z motywem stworzenia występuje w Sib. Or 6,9-17, gdzie „Syn Nieśmiertelnego” (rozumiany jako Jezus), chodząc po falach, ma w swym ręku cały świat, niebo,

36 Rdz 1-3; Pwt 32,39; 1Sm 2,6; 2Krl 5,7; Ez 37,3-12; Oz 6,2; Mdr 16,13.

37 Pierwszym komentatorem, który zwrócił uwagę na to intertekstualne odniesienie wydaje się D.F. S t r a u s s, The Life of Jesus Critically Examined, London 1898, s. 504. 
niebiosa i morze. Odniesienie do tematu stworzenia w J 6,19 przez aluzję do Hi 9,8 harmonizuje z boskim samookreśleniem się Jezusa

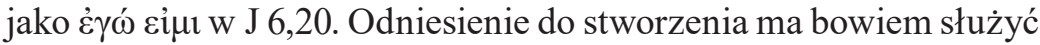
podkreśleniu boskiej tożsamości Jezusa i współgrać z następującym kontekstem literackim, gdzie Jezus objawia się jako Bóg dający mannę w czasie nowego Exodusu. ${ }^{38}$

Wzmianka o diable, mordercy i kłamcy „od początku” $(8,44)$ odsyła do węża z Rdz 3 (zob. Mdr 2,23-24) i w ten sposób przygotowuje czytelnika na odkrycie aluzji do Rdz 1-3 w opisie uzdrowienia niewidomego od urodzenia w J 9. Podobną funkcję ma wzmianka o istnieniu Jezusa ,przed Abrahamem” $(8,58)$, wskazująca na preegzystencję Jezusa, a więc istnienie przed stworzeniem świata. Zarówno w J 9,14.16, jak i w Rdz 2,2-3 obecny jest temat szabatu. Działanie w szabat wskazuje na boską tożsamość Jezusa. W J 9,3 powraca temat „dzieł Boga” ( zją do stwórczej działalności Boga. Nazwanie Jezusa „światłością świata" $(9,5)$ nawiązuje do prologu (1,4-5.9), gdzie Logos jest utożsamiony ze światłością i gdzie obecna jest idea stworzenia. Uczynienie błota $(\pi \eta \lambda$ ós) może być aluzją do ulepienia Adama z prochu ziemi

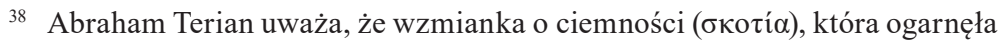

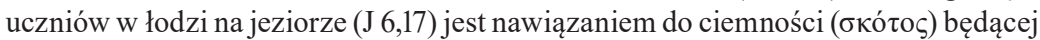
nad bezładem wód z Rdz 1,2. Patrick Madden, prócz ciemności, dodaje także silny wiatr i wzburzone morze jako przywołujące obraz pierwotnego chaosu z Rdz 1,2; zob. A. T e r i a n, Creation in Johannine Theology, w: L. M i 11 e r (red.), Good News in History. Essays in Honor of Bo Reicke, Atlanta 1993, s. 45-61; P. J. M a d d e n, Jesus' Walking on the Sea. An Investigation of the Origin of the Narrative Account, BZAW 81, Berlin 1997, s. 109. C. R. S o s a S i 1 i e z a r, Creation, s. 111, łączy obraz Jezusa, jako Boga Stworzyciela kroczącego po wodzie, z tematem „widzenia” wyrażonym czasownikiem $\theta \varepsilon \omega \rho \varepsilon ́ \omega$. Uczniowie bowiem widzieli $(\theta \varepsilon \omega \rho \varepsilon ́ \omega)$ Jezusa chodzącego po wodzie $(6,19)$. W Mt 14,26 i Mk 6,49 mowa jest o zobaczeniu (ópá $\omega$ ) ducha. W Janowym kontekście następującym Jezus mówi, że „każdy, kto widzi $[\theta \varepsilon \omega \rho \varepsilon ́ \omega]$ Syna i wierzy w niego ma życie wieczne i ja wskrzeszę go w dzień ostatni” $(6,40)$. Na innym miejscu zapisane są słowa Jezusa: „Kto widzi [ $\theta \varepsilon \omega \rho \varepsilon ́ \omega]$ mnie, widzi $[\theta \varepsilon \omega \rho \varepsilon ́ \omega]$ tego, który Mnie posłał" $(12,45)$. Ostatecznie Jezus prosi Ojca, by uczniowie widzieli $(\theta \varepsilon \omega \rho \varepsilon ́ \omega)$ chwałę, jaką otrzymał On od Ojca, wypływającą z miłości Ojca i Syna, istniejącą jeszcze przed powstaniem świata $(17,24)$. 
(Rdz 2,7). ${ }^{39}$ Termin $\pi \eta \lambda$ ós, który swoją częstotliwością występowania przykuwa uwagę czytelnika $(9,6.11 .14 .15)$, użyty jest w opisie stworzenia pierwszego człowieka w Hi 10,9 i Iz 64,7. Tekst Hioba łączy z kontekstem J 9 wzmianka o braku grzechu (J 9,2-3; Hi 10,7.14-15). Kontekst tekstu z Izajasza mówi o ludziach, którzy nie widzieli swoimi oczami innego boga poza Bogiem i Jego dziełami (ov̉ $\grave{\varepsilon}$

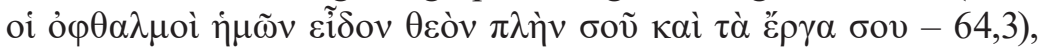
a także o ich grzechu $(64,4.5 .6) .{ }^{40} \mathrm{~W}$ moim przekonaniu, przywołaniem motywu stworzenia jest także często powracający temat grzechu (9,2-3.16.34.41). Jezus, oskarżony o bycie grzesznikiem (9,16.24.25), jest w istocie bezgrzeszny. Jezus jest tutaj symbolem nowej ludzkości, nowego Adama, pozbawionego grzechu. Do takiego stanu bezgrzeszności i nowego stworzenia (rozumianej jako wiara w Jezusa) Jezus doprowadza także uzdrowionego człowieka, oskarżonego o bycie w grzechu od urodzenia $(9,34$; por. 9,2$)$. Bycie w grzechach od urodzenia sugeruje stan upadłego stworzenia (konsekwencję upadku Adama). Upadły Adam odzyskuje swą godność

39 Christiane Koch sugeruje, że zarówno w opisie stworzenia człowieka w Rdz 2,7, jak i uzdrowienia niewidomego w J 9,6 występuje dwustopniowość czynności Boga: przygotowanie materiału (ulepienie formy człowieka/uczynienie błota) i jego użycie (tchnienie w oblicze/nałożenie na oczy). Nadto, Janowy czasownik

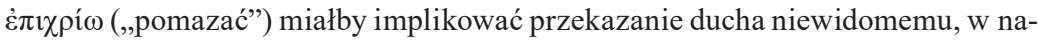
wiązaniu do tchnienia życia otrzymanego przez Adama od Boga. Fakt, że ślepota występuje „od urodzenia” ( $\dot{\varepsilon} \kappa \gamma \varepsilon v \varepsilon \tau \tilde{\varsigma}$ - 9,1; por. 9,2.19.20.32), miałby być również aluzją do idei stworzenia, gdyż uzdrowienie niewidomego winno być widziane jako akt stwórczy; zob. Ch. K o c h, Geschaffen, um Gott zu sehen. Die Heilung des Blindgeborenen als ,Schöpfungsereignis" in Joh 9,1-38, w: A. V o n a c h, G. F i s c h e r (red.), Horizonte biblischer Texte, OBO 196, Göttingen 2003, s. 205-207.

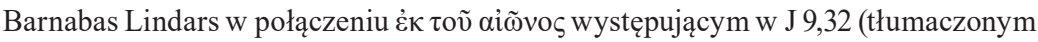
jako never since the world began), otworzeniu oczu oraz wzmiance o ślepocie od urodzenia ( $\gamma \varepsilon v v \alpha ́ \omega)$ widzi nawiązanie (a hint) do stworzenia światła, pierwszego aktu stworzenia (Rdz 1,3); B. L i n d a r s, The Gospel of John, The New Century Bible Commentary, Grand Rapids-London 1972, s. 349.

40 Więcej o powiązaniach z Izajaszem zob. J.D.M. D e r r e t t, John 9:6 Read with Isaiah 6:10; 29:9, Evangelical Quarterly 66/1994, s. 251-254; t e n ż e, Miracles, Pools, and Sight: John 9,1-41; Genesis 2,6-7; Isaiah 6,10; 30,20; 35,5-7, Bibbia e Oriente 36/1994, s. 71-85. 
bezgrzesznego stworzenia dzięki stwórczemu działaniu Jezusa, nowego Adama. Szukając potwierdzenia dla identyfikacji aluzji do stworzenia w symbolicznej czynności Jezusa w J 9,6 należy wskazać 1QS XI, 20-22, gdzie mowa jest o ludziach, zrodzonych z kobiety, którzy są utworzeni z pyłu oraz śliny, będąc uformowaną gliną. Według 1QHa XX,32-34, człowiek został stworzony z gliny i śliny. ${ }^{41}$ Interpretacja uzdrowienia niewidomego w kluczu stworzenia obecna jest już u pisarzy starożytnych (np. Ireneusz, Haer. 5,15,2-4; 5,16,1; Jan Chryzostom, Hom. Jo. 56,2). Szukając odpowiedzi na pytanie o funkcję, jaką pełni motyw stworzenia w J 9, można wskazać kwestię odkrycia właściwej tożsamości Jezusa, problem jasno zarysowany w kontekście poprzedzającym (J 7-8). W J 9 Jezus przedstawiony jest jako mający prerogatywy samego Boga, Stworzyciela, gdyż,

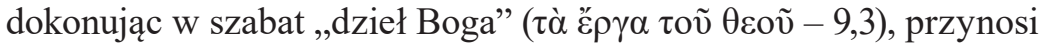
światło Bożemu stworzeniu (por. 1,9), reprezentowanemu tutaj przez człowieka niewidomego. Człowiek z ciemności (niewiary, symbolizowanej przez ślepotę) przechodzi do światła (wiary, symbolizowanej przez widzenie). Przejście z ciemności (zob. „noc”- 9,4) do światłości (zob. „światłość świata”-9,5) nawiązuje ponownie do tematu stworzenia z prologu. Akt uzdrowienia może być zatem widziany jako akt (nowego) stworzenia, Jezus zaś opisany jest jako Bóg-Stwórca. W kontekście tematu boskich (stwórczych) prerogatyw Jezusa i kwestii działania w szabat (zob. J 5) nie dziwi również fakt, że w dalszej części narracji Jezus przedstawiony jest jako sędzia ludzkości (9,39-41), ma zatem przymiot przynależny jedynie Bogu.

Podsumowując występowanie aluzji do tematu stworzenia w czterech powyższych Janowych $\sigma \eta \mu \varepsilon i ̃ \alpha$, należy zauważyć, że znajdujące się w prologu i powiązane z Jezusem i stworzeniem motywy życia i światła powracają w J 5 (kwestia życia) oraz J 9 (światło). Każdemu uzdrawianemu przez Jezusa człowiekowi przywracana jest pełnia i doskonałość, której doświadczał pierwszy człowiek w Ogrodzie Eden. Nie bez powodu zatem John Painter uważa, że wyrażenie „dobre dzieła”

${ }^{41}$ Zob. D. F r a y e r - G r i g g s, Spittle, Clay, and Creation in John 9:6 and Some Dead Sea Scrolls, Journal of Biblical Literature 132/2013, s. 659-670. 


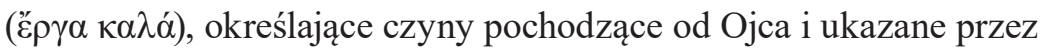
Jezusa (J 10,32), jest aluzją do stwórczej działalności Boga w Rdz 1-2. W tym sensie Jezus, przez swoje znaki, objawia i kontynuuje stwórcze dzieło Ojca, przywracając człowiekowi i ziemi jej doskonałość. ${ }^{42}$ Znak ostatni, jakim jest wskrzeszenie Łazarza, wprost zapowiada zmartwychwstanie samego Jezusa. Warto dodać, że zmartwychwstanie jako takie wiązane było w judaizmie z odnowieniem stworzenia. Jednak każdy z poprzednich znaków zapowiada ten najważniejszy znak,

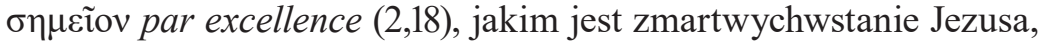
pierwszy znak realnie odnowionego stworzenia. Jednocześnie każdy z tych wcześniejszych znaków obrazuje doświadczenie człowieka zbawionego przez Niego. Skoro zaś zbawienie w Jezusie rozumiane jest już w prologu jako odnowienie czy też dopełnienie dzieła stworzenia, każdy ze znaków staje się znakiem nowego stworzenia. ${ }^{43}$

\section{Inne aluzje}

Idea „,narodzin z góry (óv $v \theta \varepsilon v)$ ) $(3,3.7)$, połączona z ideą narodzin z wody i Ducha $(3,5)$ oraz narodzin z Ducha $(3,6.8)$, widziana jest jako nawiązanie do motywu stworzenia. ${ }^{44}$ Zdaniem Hansa U. Weidemanna treści zawarte w J 3,31 (o charakterystyce człowieka pochodzącego $z$ góry - ơ $v \omega \theta \varepsilon v)$ odnoszą do opisu stworzenia człowieka, w którego nozdrza Bóg tchnął tchnienie życia $(\operatorname{Rdz} 2,27) .{ }^{45}$ Terence C. Voortman

42 J. P a i n t e r, Earth Made Whole. John's Rereading of Genesis, w: J. P a i n t e r, R. A. C u 1 p e p p e r, F. F. S e g o v i a (red.), Word, Theology, and Community in John, St. Louis 2002, s. 65-84, zwł. s. 70, 77-78.

${ }^{43}$ Zob. J. P a i n t e r, Earth, s. 77: „The sings of Jesus are miracles, new acts of creation".

${ }^{44}$ J. K o z y r a, Nowe stworzenie, s. 21; B. W it h e $\mathrm{r}$ in $\mathrm{g}$ t o n, New Creation or New Birth? Conversation in the Johannine and Pauline Literature, w: K. J. C o 11 i n s, J. H. T y s o n (red.), Conversation in the Wesleyan Tradition, Nashville 2001, s. 121-122.

45 H. U. W e i d e m a n n, The Victory of Protology Over Eschatology? Creation in the Gospel of John, w: T. N i c k 1 a s, K. Z a m f i r (red.), Theologies of Creation in Early Judaism and Ancient Christianity, DCLS 6, Berlin 2010, s. 299-334. 
uważa, że obraz Jezusa uzdrawiającego syna urzędnika jedynie za pomocą swego słowa $(4,50)$ nawiązuje do obrazu Boga stwarzającego swym słowem. ${ }^{46}$ Ruben Zimmermann natomiast twierdzi, że motyw „bramy” z J 10,1.2.7.9 może nawiązywać do bram raju, które w miał otworzyć Mesjasz (Test. Lewiego 18,10-11; por. 4Ezd 8,52). ${ }^{47}$

Dla pełności obrazu warto także wspomnieć o nie do końca przekonujących propozycjach odniesień intertekstualnych. Paul S. Minear sugerował, że określenie Jezusa jako Baranka Bożego, który usuwa grzech świata $(1,29)$ jest pewnym echem (surely an echo) narracji z Rdz 3, a zatem nawiązaniem do usunięcia grzechu Adama i Ewy dotykającego całą ludzkość, czyli świat. ${ }^{48}$ Autor ten widzi również we wzmiance o pastwisku $(\mathrm{J} 10,9)$ nawiązanie do płodnej ziemi w Rdz $1{ }^{49}$ Ruben Zimmermann widzi we wzmiance o wężu wywyższonym na pustyni $(\mathrm{J} 3,14)$ powiązanie $\mathrm{z}$ wężem z Rdz 3,1-8.10. Rajski wąż obiecał wiedzę, nie mogąc $\mathrm{w}$ istocie spełnić tej obietnicy, tymczasem Jezus, „wywyższony wąż”, prawdziwie przynosi mądrość (J 17,7-8). $\mathrm{W}$ istocie narracja Rdz 3 mówi o obietnicy wiedzy oraz obietnicy braku śmierci („Nie umrzecie!”-3,4). Ludzie w raju zdobyli poznanie dobra i zła, które obiecywał wąż (zob. 3,22), pozbawieni drzewa życia nie mogli już jednak liczyć na nieśmiertelność. Ten sam niemiecki egzegeta uważa, że tajemnicze jedzenie, o którym mówi Jezus w J 4,32-34, miałoby nawiązywać do jedzenia, które zostało przygotowane przez anioły dla Adama będącego w raju (zob. Życie Adama $i$ Ewy 4; b.Sanh. 59b). ${ }^{50}$ Trudno przyjąć jednak taką sugestię w świetle 4,34 (pokarmem Jezusa jest wola Ojca). R. Zimmermann w Janowym obrazie chleba, który jest z nieba i daje życie wieczne, a który jest inny niż chleb, który jedli przodkowie Jezusowych słuchaczy

46 T. C. V o o r t m a n, Understanding, s. 84-87.

47 R. Z i m m e r m a n n, Symbolic Communication between John and His Reader. Garden Symbolism in John 19-20, w: T. T h a t c h e r, S. D. M o o r e (red.), Anatomies of Narrative Criticism. The Past, Present, and Futures of the Fourth Gospel as Literature, SBLRBS 55, Atlanta 2008, s. 234.

48 P. S. M i n e a r, Christians and the New Creation, s. 85.

49 Tamże, s. 95.

50 R. Z i m m e r m a n n, Symbolic Communication, s. 234. 
i pomarli (J 6,58), widzi nawiązanie do Rdz 3,19, gdzie obecna jest idea zdobywania chleba w pocie czoła aż do śmierci. ${ }^{51}$ Również i to powiązanie jest nieprzekonujące, gdyż Jezus mówi o mannie, którą jedli Izraelici w czasie pobytu na pustyni, a tekst Księgi Rodzaju o konieczności pracy w celu zdobycia pożywienia w czasie ziemskiego życia. William J. Phythian-Adams sugerował, że motyw wody obecny w J 4,13-14 oraz 7,37-39 odnosi się do wód otchłani, które przed stworzeniem miały być zgromadzone pod ,pępkiem” ziemi. ${ }^{52}$ Aileen Guilding sugerowała, że obraz jedzenia i śmierci w Rdz 3 jest przywoływany w obrazie jedzenia i życia w J 6,50-51. ${ }^{53}$ Abraham Terian uważa, że światłość ( $\varphi \tilde{\omega} \varsigma$ ) w J 11,9 oraz 12,35 ma przywoływać stworzenie światłości ( $\varphi \tilde{\omega} \varsigma)$ w Rdz 1,3-5. ${ }^{54}$ Thomas Brodie widzi w fakcie zamieszkiwania Ojca i Syna (ostatecznie także i Ducha Parakleta) w wierzącym $(14,23)$ nawiązanie do koncepcji obrazu Bożego z Rdz 1,26. ${ }^{55}$ Zdaniem Craiga Keenera idea obrazu Bożego z Rdz 1,26 miałaby być także tłem opisu uzdrowienia paralityka w J $5 .{ }^{56}$

\section{Księga Chwały}

Modlitwa Arcykapłańska Jezusa zawiera dwa wyraźne odniesie-

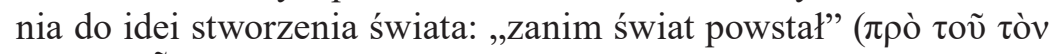

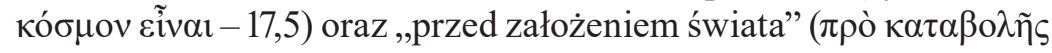

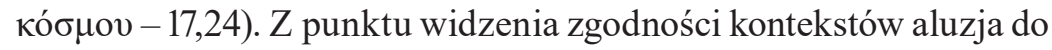

${ }^{51}$ Tamże, s. 233.

52 W. J. P h y t h i a n - A d a m s, The New Creation in St. John, Church Quarterly Review 144/1947, s. 69.

${ }_{53}$ A. G u i 1 d in g, The Fourth Gospel and Jewish Worship: A Study of the Relation of St. John's Gospel to the Ancient Jewish Lectionary System, Oxford 1960, s. 61-53.

${ }^{54}$ A. T e r i a n, Creation, s. 45-61.

55 T. L. B r o d i e, The Gospel according to John. A Literary and Theological Commentary, New York 1993, s. 467.

56 C. S. K e e n e r, The Gospel of John. A Commentary, Peabody 2003, s. 649. 
Prz 8,23-25 i Mdr 7,25 jest mało przekonująca. ${ }^{57}$ Odniesienia do stworzenia świata są umieszczone na początku i końcu modlitwy Jezusa, tworząc tematyczne inclusio. Obie aluzje łączą przeszłość z teraźniejszością i przyszłością. Oto chwała, którą Jezus był otoczony jeszcze przed stworzeniem świata, zostanie objawiona przez Ojca, tak by mogła być widziana przez uczniów Jezusa. Obie aluzje podkreślają prawdę o istnieniu Jezusa - nie jest to już enigmatyczny ó $\lambda$ ó $\gamma$ o $\varsigma$ $\mathrm{z}$ prologu - wraz Ojcem w stanie chwały jeszcze przed stworzeniem świata. W odróżnieniu do prologu, Jezus w J 17,5.24 nie jest opisany jako aktywnie uczestniczący w stworzeniu. Tak jak w 1,10 świat zo-

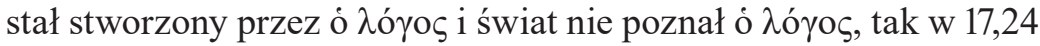
świat nie poznał Ojca, choć tekst sugeruje implicite stworzenie tego świata przez Ojca. Zdaniem C. R. Sosa Siliezara sens aluzji do Rdz 1 w J 17,5.24 doskonale wpisuje się w globalny cel Janowych odniesień do stworzenia, a jest nim podkreślenie bardzo bliskiej relacji między Ojcem i Jezusem. ${ }^{58}$ Idea stworzenia obecna w prologu, na początku narracji, wypowiedziana ustami narratora, jest ponownie przywołana explicite przy jej końcu, bezpośrednio przez męką i śmiercią Jezusa, ustami samego Jezusa.

Aluzje do Rdz 1-2 w Janowym opisie męki i zmartwychwstania Jezusa są liczne i stały się przedmiotem wielu opracowań. Omówimy wpierw aluzję najbardziej oczywistą, dotyczącą tchnienia na uczniów Ducha Świętego, by następnie przejść na aluzji mniej oczywistych i na końcu wspomnieć o proponowanych, zupełnie nieprawdopodobnych, odniesieniach intertekstualnych.

Powiązanie tchnienia zmartwychwstałego Jezusa (J 20,22) z obrazem Boga Stworzyciela tchnącego w twarz ulepionego z prochu ziemi człowieka (Rdz 2,7) nie budzi poważnych wątpliwości. Tak jak Bóg

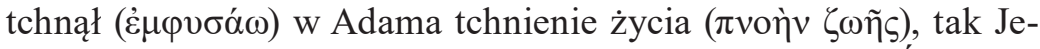

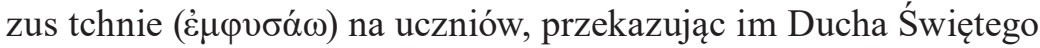
( $\pi v \varepsilon \tilde{v} \mu \alpha$ ö $\gamma 10 v)$. Warto podkreślić, że obu tekstach występuje ta sama

57 Zob. szczegółowe analizy porównawcze C. R. S o s a S i 1 i e z a r, Creation, s. 56-57.

58 Tamże, s. 64. 


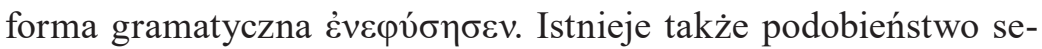
mantyczne między $\pi v o \eta ́ ~ a ~ \pi v \varepsilon \tilde{v} \mu \alpha$, odwołujące się do idei wiatru.

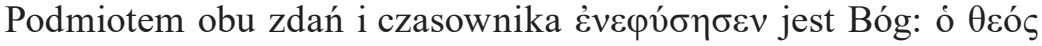
(Rdz 2,7) i ó 'Inбoṽ (J 20,19.21). Tchnienie w obu przypadkach jest jednorazowe. Przekonanie, że Bóg tchnął swego ducha w akcie stworzenia człowieka jest obecne w judaizmie okresu powstawania Nowego Testamentu. Według Księgi Mądrości 15,11 Bóg tchnął w Adama

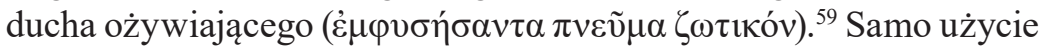
czasownika $\dot{\varepsilon} \mu \varphi v \sigma \alpha ́ \omega$ również zawiera konotacje związane z przekazaniem życia. Otóż w 1Krl 17,21 LXX Eliasz tchnie ( $\dot{\varepsilon} \mu \varphi v \sigma \alpha ́ \omega)$ na chłopca, przywracając mu życie. W Ez 37,9 LXX Ezechiel z roz-

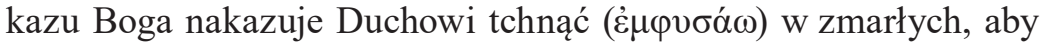

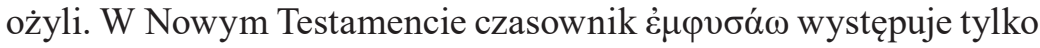
w J 20,22, co jest bez wątpienia kolejną wskazówką do interpretowania sceny przekazania Ducha Świętego w kontekście odnowienia stworzenia. Wiązanie tchnienia z J 20,22 z Rdz 2,7 obecne jest także w pismach Ojców Kościoła, co jest następnym argumentem (spełnieniem wstępnego kryterium) za uznaniem istnienia aluzji. ${ }^{60}$ Szukając znaczenia tej aluzji do interpretacji J 20, należy zauważyć, że czytelnik automatycznie dostrzega boską tożsamość Zmartwychwstałego, który jest w takiej samej relacji z Ojcem jak Logos z prologu (1,1-2). ${ }^{61}$ Tylko Bóg ma bowiem prerogatywę obdarzania Duchem. ${ }^{62}$ Jezus, dokonując aktu nawiązującego do czynności Boga

59 Idea przekazania ducha w czasie aktu tchnienia w Rdz 2,7 obecna jest u Fi-

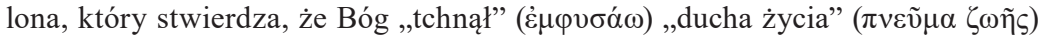
(Det. Pot. Ins. 80; Leg. All. 3,161). Stworzony przez Boga człowiek jest, zdaniem Filona, „duchem boskim” ( $\pi v \varepsilon v ́ \mu \alpha \tau o \varsigma$ $\theta \varepsilon i ́ o v)$, gdyż otrzymał „boskiego ducha” ( $\pi v \varepsilon \tilde{v} \mu \alpha \theta \varepsilon \tilde{\imath} о v)$ (Op. Mund. 135).

${ }_{60}$ Teodor z Mopsuesti i, Comm. Jo. 7,20-22; Cyryl Jerozolimski, Myst. Cat. 17,12; C y ryl A le k s a n d ry j s k i, Comm. Jo. 12.

${ }_{61}$ Zob. M. M. T h o m p s o n, The Breath of Life. John 20:22-23 Once More, w: G.N. S t a n t o n, B. W. L o n g e n e c k e r, S. C. B a r t o n (red.), The Holy Spirit and Christian Origins, Grand Rapids 2004, s. 71, 77.

${ }^{62}$ C.S. K e e n e r, John, s. 1205. Autor przywołuje wiele tekstów ST potwierdzających tę tezę. 
Stworzyciela w Rdz 2,7, wskazuje także na cały świat jako na adresatów swej misji zbawczej. W efekcie misja uczniów Jezusa, posłanych z nakazem odpuszczania i zatrzymywania grzechów, ma zasięg uniwersalny. ${ }^{63}$ Niektórzy autorzy wskazują ten moment Ewangelii Jana jako jej moment kulminacyjny. Nie bez znaczenia jest fakt, że tchnienie Zmartwychwstałego znajduje się w centrum trzech opisów chrystofanii w J $20{ }^{64}$

Kolejną powszechnie przyjmowaną aluzją do Rdz 1-3 w Janowym opisie męki i zmartwychwstania Jezusa jest motyw ogrodu. Zarówno aresztowanie Jezusa, jak i jego ukrzyżowanie i złożenie do grobu

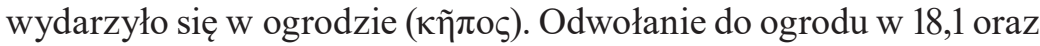
19,41 tworzy inclusio całej narracji o męce i śmierci Jezusa, przywo-

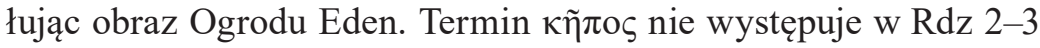
w tłumaczeniu LXX (13 razy występuje tam $\pi \alpha \rho \alpha ́ \delta \varepsilon 1 \sigma o \varsigma)$, ale spotykamy go w przekładach Akwili (Rdz 2,8; 3,2) oraz Teodocjona $(3,2)$. Nie chodzi jednak o dosłowną paralelę terminologiczną, ale o tożsamość idei. Szukając jednak werbalnych paraleli, należy zauważyć, że termin $\kappa \tilde{\eta} \pi$ ऽ funkcjonuje jako synonim $\pi \alpha \rho \alpha ́ \delta \varepsilon 1 \sigma o \varsigma$ w Koh 2,5 oraz Syr 24,30-31. Nadto, w Ez 36,35 LXX rajski Eden określony jest

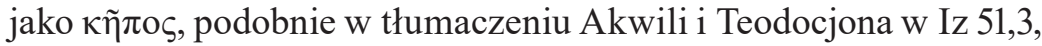

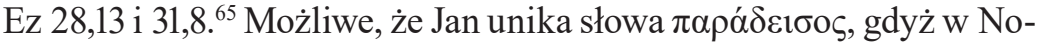
wym Testamencie jest ono używane na określenie niebiańskiej (nadprzyrodzonej) rzeczywistości raju (zob. Łk 23,43; 2Kor 12,4; Ap 2,7).

63 Aspekt ten omawia szeroko C. R. S o s a S i 1 i e z a r, Creation, s. 169-172.

${ }^{64}$ E. M. H u m p h r e y, New Creation, w: K. J. V a n h o o z e r (red.), Dictionary for Theological Interpretation of the Bible, Grand Rapids 2005, s. 536: „The climax of the Fourth Gospel presents Jesus as 'breathing' upon the apostles after the pattern of the creating God who breathed upon the Edenic couple; now they receive the Spirit, and not simply the gift of life"; C. R. S o s a S i 1 i e z a r, Creation, s. 161: „This instance of creation imagery occupies a strategic place in John”. Powiązanie J 20,22 z targumiczną lekturą Rdz 2,7 prezentują M. W o j c i e c h o w s k i, Le don de L'Esprit Saint dans Jean 20.22 selon Tg. Gn. 2.7, New Testament Studies 33/1987, s. 289-291; T. R. H a t i n a, John 20,22 in Its Eschatological Context: Promise or Fulfilment? Biblica 74/1993, s. 196-219.

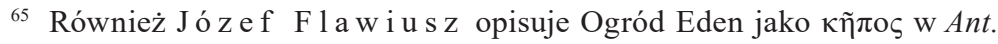
$1,38.45 .51$. 


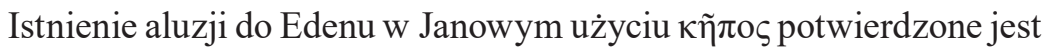
także obecnością tego odniesienia w egzegezie patrystycznej (np. Cyryl Jerozolimski, Myst. Cat. 13,19; Cyryl Aleksandryjski, Comm. Jo. 11-12). ${ }^{66}$ Janowe odniesienie do Ogrodu Eden, w kontekście męki i zmartwychwstania Jezusa miałoby pokazać ponowną dostępność raju dla odkupionej przez Jezusa ludzkości. W takim sam spos,ób w jaki kończy się Apokalipsa Janowa (Ap 21-22), kończy się zatem również czwarta Ewangelia (J 18-20).

Kolejne aluzje do Rdz 1-3 w Janowym opisie męki i zmartwychwstania Jezusa (J 18-20) są mniej ewidentne. Edwin C. Hoskyns sugerował, że obraz Jezusa skłaniającego głowę na krzyżu ( $\kappa \lambda i ́ v \alpha \varsigma$ $\tau \eta ̀ v ~ \kappa \varepsilon \varphi \alpha \lambda \eta ́ v-19,30)$ nawiązuje do obrazu śpiącego Adama, z którego boku powstaje Ewa (Rdz 2,21-22). Tak jak Boży Duch w Rdz 1,2 jest narzędziem stworzenia, tak przekazany na krzyżu, w momencie śmierci Jezusa, Duch, jest narzędziem powtórnego stworzenia. Stojąca pod krzyżem matka Jezusa winna być zatem identyfikowana z Ewą, małżonką Adama. Nazwanie Maryi przez Jezusa słowem „kobieta" ( $\gamma v v \eta ́)$ nawiązuje zatem do tekstów dotyczących Ewy w Rdz 2,23 i 3,20. ${ }^{67}$ Identyfikacja Maryi jako nowej Ewy znana jest już w starożytności. ${ }^{68}$ Jednocześnie Maryja, nowa Ewa, razem z anonimowym umiłowanym uczniem tworzą rzeczywistą oblubienicę Boga,

66 Więcej F. M a n n s, Le symbolisme du jardin dans le récit de la passion selon St Jean, Liber Annuus 37/1987, s. 53-80; R. Z i m m e r m a n n, Symbolic Communication, s. 221-235. Mariusz R o s i k, Interpretacja, s. 54, uważa, że wzmianka o „wczesnym ranku” w J 20,1 może nawiązywać do lokalizacji Edenu „na wschodzie” (Rdz 2,8). „Na wschodzie” miałoby oznaczać „od strony poranka”, wskazując na symbolikę budzącego się życia. Krytyczną ocenę tego intertekstualnego powiązania

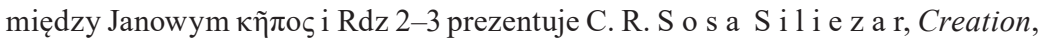
s. 179-190. W jego opinii, jedynym możliwym intertekstualnych odniesieniem związanym z Janowym $\kappa \tilde{\eta} \pi$ o jest starotestamentowa idea królewskiego ogrodu (zob. 2 Krl 25,4; Est 7,7-8; Koh 2,5; Jr 52,7). Warto jednak podkreślić, że J ó z e f

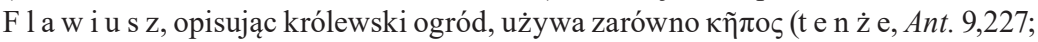
11,265), jak i $\pi \alpha \rho \alpha ́ \delta \varepsilon 1 \sigma o \varsigma$ (tamże, 10,46).

67 E. C. H o s k y n s, Genesis, s. 211.

68 Robi to już J u s t y n M ę c z e n n i k, zmarły przed 167 r., choć w kontekście Łk 1,35 (t e n ż e, Dial. 100). 
nową Ewę, Kościół. Nie bez znaczenia jest fakt, że ukrzyżowanie ma miejsce w piątek, szóstego dnia tygodnia, co przywołuje szósty dzień pierwszego tygodnia stworzenia, który był dniem stworzenia Adama i Ewy (Rdz 1,24-31). Maryja i umiłowany uczeń, tworzący Kościół, stają się nową ludzkością czy też odnowioną ludzkością. $\mathrm{Z}$ mojej strony chciałbym zwrócić uwagę na rabinackie teksty mówiące o grzechu Adama, który miał nastąpić szóstego dnia o godzinie dziesiątej. ${ }^{69}$ Powołanie pierwszych dwóch uczniów Jezusa, w tym jednego nieznanego z imienia i którym może być anonimowy umiłowany uczeń z 19,26, stało się właśnie o godzinie dziesiątej $(1,39)$. Możemy zatem mówić o odwróceniu sytuacji z Ogrodu Eden przez dzieło Jezusa. Nowymi Adamem i Ewą, przywróconymi do stanu rajskiego, jest wspólnota Kościoła. W tym kluczu Maria Magdalena, nazwana przez Jezusa „kobietą” $(20,15)$, jest także figurą nowej Ewy i wspólnoty Kościoła. Nazwanie Marii po imieniu przez Jezusa $(20,16)$ może być również nawiązaniem do nazwania przez Adama pierwszej kobiety Ewą (Rdz 3,20). ${ }^{70}$ Tak jak pierwsza Ewa była nieposłuszna nakazowi Boga, tak nowa Ewa, symbolizowana przez Marię Magdalenę, jest posłuszna nakazowi Jezusa i zanosi braciom Jezusa wieść o Jego zmartwychwstaniu. ${ }^{71}$

Niektórzy egzegeci widzą nawiązanie do wypełnienia dzieła Boga w słowach Jezusa na krzyżu: „Kiedy Jezus wiedział, że wszystko się

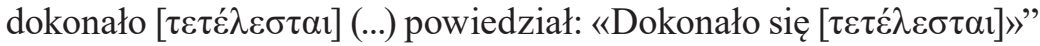
$(19,28.30)$. Obecną tutaj ideę „dokonania się” ( $\tau \varepsilon \lambda \dot{\varepsilon} \omega)$ komentatorzy wiążą z ideą „wypełnienia” ( $\tau \varepsilon \lambda \varepsilon 1 o ́ \omega)$ przez Jezusa dzieł Ojca obecną

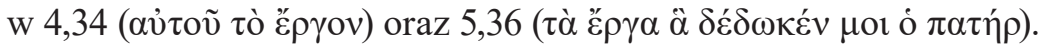
Co ciekawe, w opisie stworzenia w Rdz 1-2 pojawia się również

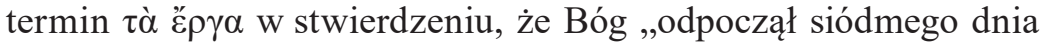

69 Zob. Pesiq. Rab. 46,2; Pesiq. Rab Kah. 23,1; Midr. Ps. 92 §3; Lev. Rab. 29.1.

70 Zob. A. R e i n h a r t z, To Love the Lord. An Intertextual Reading of John 20, w: F. C. B 1 a c k, R. B o e r, E. R u n i o n s (red.), The Labour of Reading. Desire, Alienation, and Biblical Interpretation, SBL Semeia Studies 36, Atlanta 1999, s. 63.

${ }_{71}$ M. L. C o 1 o e, Theological Reflections on Creation in the Gospel of John, Pacifica 24/2011, s. 8: „The woman in the garden of John 20 reverses the actions and consequences of the woman in the garden of Genesis". 


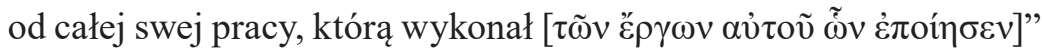
$(2,2)$. Obecny jest również pochodny do Janowego $\tau \varepsilon \lambda \varepsilon \dot{\varepsilon} \omega$ czasownik wyrażający ideę dokonania się, $\sigma v v \tau \varepsilon \lambda \varepsilon \dot{\varepsilon} \omega$, w zdaniu „niebo i zie-

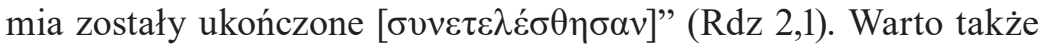
zauważyć, że w J 19,31, bezpośrednio po przytoczeniu ostatniego słowa Jezusa z krzyża, dwukrotnie pojawia się wzmianka o szabacie

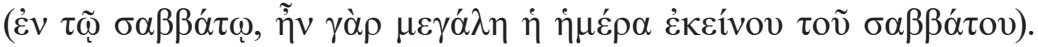
Wzmianka ta miałaby nawiązywać do siódmego dnia stworzenia, do szabatu Boga, z Rdz 2,2-3. Istnienie powyższego powiązania intertekstualnego między J 19,28-31 i Rdz 1-2 sugeruje niekompletność stworzenia opisanego w Rdz 1-2 od samego początku jego istnienia, a zatem jeszcze przed grzechem człowieka. Pełnia stworzenia, czy też dokończenie dzieła stworzenia, następuje zatem dopiero wraz z działaniem Jezusa, Jego odpoczynkiem w czasie szabatu i Jego powstaniem z martwych w pierwszym dniu nowego tygodnia dopełnionego stworzenia. ${ }^{72}$

W chronologii Janowej, Jezus umiera w piątek i pozostaje w grobie w szabat, ostatni dzień tygodnia. Zmartwychwstanie Jezusa następuje pierwszego dnia tygodnia. Informacja ta nie jest akcydentalna, skoro

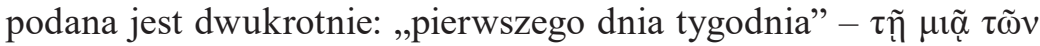

72 M. He n g e 1, The Old Testament in the Fourth Gospel, Horizons in Biblical Theology 12/1990, s. 33-34; J. K. B r o w n, Creation's Renewal, s. 285-286. Na temat dopełnienia dzieła stworzenia przez Jezusa i Jego uczniów (Kościół), zob. także R.T. S t a m m, Creation and Revelation in the Gospel of John, w: J.M. M y e r s (red.), Search the Scripture: New Testament Studies in Honor of Raymond T. Stamm, Leiden 1969, s. 13-32; S. M. M c D o n o u g h, Christ as Creator. Origins of a New Testament Doctrine, Oxford 2009, s. 213-234. Oczywiście odniesienie do wypełnienia się dzieła Jezusa nie jest jedyną interpretacją J 19,28-30. Tekst mówi również o wypełnieniu się Pism; zob. szerzej R. V i g n o 1 o, La morte di Gesù nel Quarto Vangelo come compimento, w: G. G h i b e r t i (red.), Opera Giovannea, Logos. Corso di studi biblici 7, Torino 2003, s. 273-292 (autor ten mówi o czterech wypełnieniach: misji Jezusa, Pism, Jezusowej miłości [zob. 13,1] i Jezusowego pragnienia); C. M a r i a n o, Tetelestai. Il significato della morte di Gesù alla luce del compimento della Scrittura in Gv 19,16b-37, Quaderni della rivista di scienze religiose 14, Roma 2010. Niewłaściwe jest jednak ograniczanie interpretacji J 19,28-30 jedynie do wypełnienia się Pism. 
$\sigma \alpha \beta \beta \alpha ́ \tau \omega \nu(20,1)$ oraz „gdy był wieczór tego dnia, pierwszego dnia

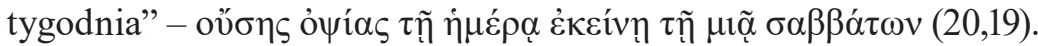
Pierwszy dzień tygodnia jest przywołany raz jeszcze w narracji, gdy ewangelista wspomina o ponownej chrystofanii „po ośmiu dniach"

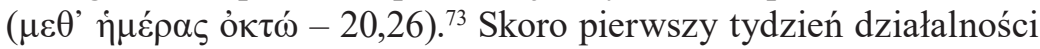
Jezusa przywołuje pierwszy tydzień stworzenia, także ostatni tydzień życia Jezusa może przywoływać pierwszy tydzień stworzenia z Rdz 1. Tak jak Bóg odpoczął po swojej pracy stwórczej siódmego dnia (Rdz 2,2-3), tak i Jezus odpoczywa w szabat w grobie po wykonaniu pracy zleconej mu przez Ojca. Zmartwychwstanie, przypadające na pierwszy dzień nowego tygodnia, może zatem wskazywać na nowe stworzenie. ${ }^{74}$

Dwóch aniołów w grobie Jezusa $(20,12)$ może nawiązywać do dwóch cherubów strzegących wejścia do Ogrodu Eden $(\operatorname{Rdz} 3,24){ }^{75}$

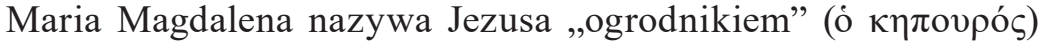
$(20,15)$, co przywołuje obraz Boga, który zasadził Ogród Eden (Rdz 2,8), oraz Adama, umieszczonego w raju z zadaniem wykonywania pracy ogrodnika $(\operatorname{Rdz} 2,15) .{ }^{76}$ Odwołując się do starożytnej

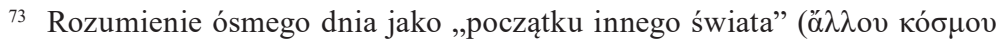

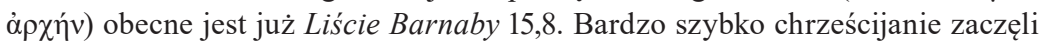
utożsamiać ósmy dzień z dniem zmartwychwstania i nowego stworzenia. Dla przykładu, J u s t y n M ę c z e n n i k interpretuje przypadające w tradycji żydowskiej ósmego dnia obrzezanie jako typ prawdziwego obrzezania, które dokonało się ósmego dnia i którym było usunięcie błędu i zła z sprawą zmartwychwstania Jezusa (t e n ż e, Dial. 41,4).

74 Na temat roli Janowego szabatu czytanego w kluczu stworzenia zob. A.J. D r o g e, Sabbath Work / Sabbath Rest: Genesis, Thomas, John, History of Religions 47/2007-2008, s. 112-141.

75 Np. J. N. S u g g i t, Jesus the Gardener. The Atonement in the Fourth Gospel as Re-creation, Neotestamentica 33/1999, s. 167; M. R o s i k, Interpretacja, s. 48-50; $\mathrm{t}$ e $\mathrm{n} \dot{\mathrm{z}} \mathrm{e}$, Discovering the Secrets of God's Gardens. Resurrection as New Creation (Gen 2:4b-3:24; Jn 20:1-18), Liber Annuus 58/2008, s. 91-93.

76 N. W y a t t, "Supposing Him to Be the Gardener" (John 20,15). A Study of the Paradise Motif in John, ZNW 81/1990, s. 21-38. C. R. S o s a S i 1 i e z a r, Creation, s. 174-179, neguje istnienie powyższego powiązania, wskazując, że w judaizmie okresu Drugiej Świątyni nie określano ani Boga, ani Adama mianem ogrodnika. 
bliskowschodniej idei króla jako ogrodnika (np. „ogrodnik” był oficjalnym tytułem królów w Mezopotamii), Jezus byłby widziany jako król w swoim ogrodzie nowego stworzenia, na wzór Adama, królewskiego ogrodnika w Edenie.77 Aluzja do Ogrodu Eden w J 20,15 została dostrzeżona przez św. Hieronima (Hom. 87).

Grzech pierwszych ludzi wprowadził w świat lęk przed boskością $(\operatorname{Rdz} 3,10)$. Brak lęku Marii Magdaleny w stosunku do aniołów w J 20,11-14 jest zdumiewający w porównaniu z narracjami synoptycznymi mówiącymi o lęku kobiet wobec angelofanii (zob. Mt 28,4-6; Mk 16,5-6; Łk 24,5). Lęk przed Bogiem, który pojawia się po raz pierwszy w Ogrodzie Eden, znika w nowym Edenie, którym jest ogród Jezusa Mesjasza, za sprawą zmazania grzechów przez Jezusa-Przebłagalnię. ${ }^{78}$

Jezus jest, jak się wydaje, identyfikowany z drzewem poznania dobra i zła oraz drzewem życia. Zakaz dotykania drzewa dobra i zła (Rdz 3,3) został odwrócony, gdyż Maria Magdalena dotyka Jezusa, ${ }^{79}$ tak jak później zachęcony jest do tego Tomasz $(20,27)$. Tak jak drzewa zostały stworzone trzeciego dnia ( $\operatorname{Rdz} 1,11-12)$, a wśród nich drzewo życia i drzewo poznania dobra i zła, tak trzeciego dnia (2,19-20)

Faktem jest jednak, że F i l o n określa Boga jako $\varphi v \tau o v \rho \gamma o ́ \varsigma$ „pielęgnujący rośliny lub drzewa" (t e n ż e, Conf. Ling. 196; t e n ż e, Plant. 2). Termin ten Plutarch używa w znaczeniu rzeczownikowym jako, ,ogrodnik”; zob. Z. A b r a m o w i c z ó w n a, Słownik grecko-polski, Warszawa 1958, t. 4, s. 577. Oczywiste jest też, że biblijny obraz Boga zasadzającego Ogród Eden był powszechnie znany (zob. 4Q504 8,6; Jó z ef Flaw i u s z, Ant. 1,37; 4 Ezd 3,5-6; 1Hen. 25,4-7; 2Bar 4,3).

77 Tak J. S c h a p e r, The Messiah in the Garden. John 19.38-41, (Royal) Gardens, and Messianic Concepts, w: M. B o c k m u e h 1, G. G. S t r o u m s a (red.), Paradise in Antiquity. Jewish and Christian Views, Cambridge 2010, s. 17-27; A. K u b i ś, The Book of Zechariah in the Gospel of John, Études bibliques 64, Pendé 2012, s. 464-465. Odnośnie do starożytnego tła zob. G. W i d e n g r e n, The King and the Tree of Life in Ancient Eastern Religion (King and Saviour IV), UUA 1951/1954, Uppsala-Leipzig 1951.

78 Szerzej A. K u b i ś, Znaczenie pozycji aniołów w grobie Jezusa w J 20,12, Biblical Annals 6/2016, s. 482-485.

79 Forma gramatyczna wyrażenia $\mu$ ஸ́ $\mu$ ov ő̃ $\tau$ ov w J 20,17 dopuszcza tłumaczenie: „Przestań mnie dotykać”. 
objawia się Jezus, prawdziwe drzewo życia, do którego mają przystęp wszyscy. Według 1Hen. 25,4 dotykanie drzewa życia nastąpi dopiero w czasie wielkiego sądu, kiedy drzewo zostanie udostępnione sprawiedliwym i pobożnym, a jego owoce - wybranym (por. 3Hen. 23,28; Test. Lewiego 18,10-11). Samo drzewo zaś przeniesione będzie do świątyni Boga. W świetle Jub. 3,10-13 dotykanie drzewa jest zabronione, gdyż jest ono identyfikowane ze świętością i sanktuarium. Powyższe dane doskonale korespondują z teologią Janową. ${ }^{80}$

Spośród mniej przekonujących powiązań intertekstualnych między Rdz 1-3 a Janową Księgą Chwały można wymienić następujące sugestie egzegetów. Edwin C. Hoskyns sugerował obecność w J 16,21 aluzji do Rdz 2,23. Tak jak bezimienna kobieta ( $\gamma v v \eta ́)$ w J 16,21 jest obarczona cierpieniem, tak i w Rdz 3,16 bezimienna kobieta ( $\gamma v v \eta ́)$, później identyfikowana z Ewą (3,20), jest obarczona cierpieniem. Zdaniem niektórych egzegetów Piłatowe wyrażenie $(19,5)$ odnosi się na głębszym poziomie (fenomen double entendre) do typologii Adamowej, prezentując Jezusa jako antytyp rajskiego Adama ${ }^{81} \mathrm{Zdaniem}$ M.L. Coloe, opis miejsca ukrzyżowania Jezusa pośrodku ( $\mu \varepsilon ́ \sigma o v)$ dwóch innych osób $(\mathrm{J} 19,18)$ jest echem zasadzenia przez Boga drzewa

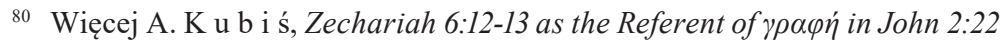
and 20:9. A Contribution to Johannine Temple-Christology, Biblical Annals 2/2012, s. 177-181; t e n ż e, Znaczenie, s. 484-485. Możliwość powiązania zakazu dotyku wydanego przez Jezusa z osobą Adama zabraniającego Ewie dotyku swego ciała (Apok. Mojżesza 31,3-4) omawia M. R. D’A n g e l o, A Critical Note: John 20:17 and Apocalypse of Moses 31, Journal of Theological Studies 41/1990, s. 532-533. W Jezusowym zakazie dotykania go przez Marię Magdalenę Adele Reinhartz widzi odwrócenie sytuacji opisanej w Rdz 2,24. Relacja między mężczyzną i kobietą nakierowana jest na bycie razem, stanie się ,jednym ciałem”. Relacja z Jezusem wymyka się jednak tym kategoriom; A. R e i n h a r t z, To Love the Lord, s. 63. Alison Jasper uważa Jezusowy zakaz dotyku za nawiązanie do brutalnego wyrzucenia pierwszych ludzi z Edenu. W obu przypadkach akt odrzucenia następuje po pokazaniu braku adekwatnej wiedzy; A. J a s p e r, Interpretative Approaches to John 20,1-18. Mary at the Tomb of Jesus, Studia Theologica 47/1993, s. 107-117.

${ }^{81}$ M. D. L i t w a, Behold Adam. A Reading of John 19:5, Horizons in Biblical Theology 32/2010, s. 129-143; J.K. B r o w n, Creation's Renewal, s. 281. 
życia pośrodku (̇̉v $\mu \varepsilon ́ \sigma \omega)$ ogrodu $(\operatorname{Rdz} 2,9) .{ }^{82}$ Yves Simoens widzi we wzmiance o ciemności w J 20,1 odniesienie do pierwszego dnia stworzenia, podkreślając obecność idei oddzielania ciemności od jasności, jako jednego z charakterystycznych motywów Janowych. ${ }^{83}$

Nie brak także nieprzekonujących propozycji łączących Księgę Chwały z Rdz 1-3. Raymond T. Stamm sugerował, że nakaz bycia płodnymi i rozmnażania, w celu zaludnienia ziemi ( $R d z 1,28)$, a także nakaz uprawiania i doglądania Ogrodu Eden $(\operatorname{Rdz} 2,15)$ są wciąż obowiązujące i są odzwierciedlone w stwierdzeniu Jezusa: „Kto trwa we mnie, a Ja w nim, ten przynosi owoc obfity" (J 15,5) ${ }^{84}$ Inną paralelą tematyczną (conceptual parallel) jest intymna bliskość między Stworzycielem i stworzonym człowiekiem, jaka istniała w Ogrodzie Eden, gdy Bóg przechadzał się w nim gotowy do spotkania i rozmowy z Adamem, a obrazem przywróconej intymnej bliskości między Stwórcą i człowiekiem, wyrażonym przez spoczywanie umiłowanego ucznia na piersi Jezusa $(\mathrm{J} 13,23) .{ }^{85}$ Inną w naszym przekonaniu nieprawdopodobną aluzją byłoby spotkanie między Jezusem

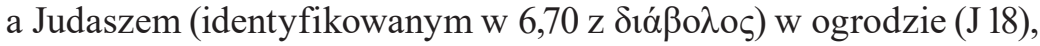
które miałoby przywoływać obraz walki Adama z wężem w Rdz 2-3. ${ }^{86}$ Przede wszystkim Adam nie walczy z wężem w Rdz 2-3, tak samo jak Jezus nie walczy z Judaszem w J 18,3. Nadto scena aresztowania Jezusa wcale nie musi się rozgrywać w ogrodzie, skoro użyty jest

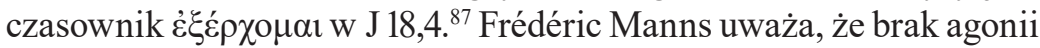
Jezusa w J 18,1-12 nawiązywałby do biblijnej koncepcji „ogrodu rozkoszy” (Rdz 3,23.24; J1 2,3; Ez 28,13; 31,9; 36,35). Koncepcję „chwały Adama”, szeroko potwierdzoną w literaturze międzytestamentalnej,

82 C. M. C o 1 o e, Creation, s. 5.

83 Y. S i m o e n s, Selon Jean, Collection IET 17, Bruxelles 1997, t. 3, s. 867.

84 R. T. S t a m m, Creation, s. 14.

85 Tamże, s. 19.

86 Tak S. A. H u n t, The Roman Soldiers at Jesus' Arrest: "You Are Dust, and to Dust You Shall Return”, w: S. A. H u n t, D. F. T o 1 m i e, R. Z i m m e r m a n n (red.), Character Studies in the Fourth Gospel. Narrative Approaches to Seventy Figures in John, WUNT I/314, Tübingen 2013, s. 554-567.

${ }_{87}$ Szeroką krytykę przeprowadza C. R. S o s a S i 1 i e z a r, Creation, 22. 
należy powiązać z chwałą Jezusa objawioną w ogrodzie w czasie

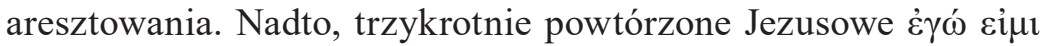
w scenie aresztowania $(18,5.6 .8)$ może nawiązywać do przekonania o obecności chwały Bożej Szekinah, mającej zamieszkiwać Eden. ${ }^{88}$

$\mathrm{Z}$ pewną dozą sceptycyzmu, David F. Ford sugerował, że czasownik $\pi$ oı́́ $\omega$ w J 20,30 oraz 21,25 przywołuje Rdz 1,1.89; J. N. San-

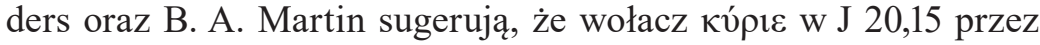
swoją dwuznaczność może przywoływać boską tożsamość Jezusa i pośrednio czynić aluzję do obecności Boga w Ogrodzie Eden. ${ }^{90}$ Zdaniem R. Zimmermanna rozpoznanie Jezusa przez Marię Magdalenę następuje dzięki głosowi Jezusa, co stanowi aluzję do ,słuchania głosu" w J 10,3.4.27, ale również w Rdz 3,8.10 Bóg i Jezus, których głos jest słyszany, ,przechadzają" się w ogrodzie (Rdz 3,8) i świątyni $(\mathrm{J} 10,23) .{ }^{91}$ Porównanie to jest zupełnie nieprzekonujące, gdyż usłyszenie głosu Boga w raju jest powodem lęku i ukrycia się ludzi, natomiast słuchanie głosu Jezusa jest gwarantem zbawienia. Nadto, Maria nie tyle rozpoznanie Jezusa po głosie (który słyszy już wcześniej w słowach „Kobieto, dlaczego płaczesz?”), ile po usłyszeniu swojego imienia. Mariusz Rosik dostrzega powiązanie między motywem poznania z Rdz 3,5.22 i szukania z Rdz 3,9 a szukaniem i poznaniem Zmartwychwstałego przez Marię Magdalenę (następuje odwrócenie kolejności motywów). W obu przypadkach Bóg

${ }^{88}$ F. M a n n s, Le symbolisme du jardin, s. 70-71, 74; t e n ż e, L'Évangile de Jean à la lumière du Judaïsme, SBLA 33, Jerusalem 1991, s. 417-418, 422. Nazwa

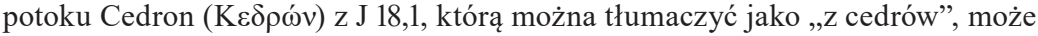
nawiązywać do „cedrów z ogrodu Boga” w Ez 31,8; tak B. P. R o b i n s o n, Gethsemane. The Synoptic and the Johannine Viewpoints, Church Quarterly Review 167/1966, s. 4-11.

89 D. F. F o r d, Beginning, Ending and Abundance. Genesis 1:1 and the Gospel of John, w: D. A. B a e r, R. P. G o r d o n (red.), Leshon Limmudim. Essays on the Language and Literature of the Hebrew Bible, LHBOTS 593, London 2013, s. 293.

90 J. N. S a n d e r s, B. A. M a s t i n, A Commentary on the Gospel of St. John, London 1968, s. 426; N. W y a t t, "Supposing Him to Be the Gardener" (John 20,15, s. 38 .

91 R. Z i m m e r m a n n, Symbolic Communication, s. 231. 
zwraca się do osób po imieniu ( $\mathrm{Rdz} 3,9 ; 20,16) .{ }^{92}$ Zmiana czasowników opisująca sposób widzenia Marii Magdaleny ( $\beta \lambda \dot{\epsilon} \pi \omega-20,1$; $\theta \varepsilon \omega \rho \varepsilon ́ \omega-20,12.14$; ópó $\omega$ - 20,18) może być odniesiona do zmiany w sposobie widzenia Adama i Ewy, gdy ich oczy zostały otworzone. ${ }^{93}$ Wrocławski egzegeta wiąże także zakaz spożywania owocu z drzewa poznania dobra i zła $(\mathrm{Rdz} 2,16-17 ; 3,5)$ z zakazem dotykania Jezusa przez Marię Magdalenę, ${ }^{44}$ fakt przyodziania pierwszych ludzi przez Boga okryciami ze skór ( Rdz 3,21) z szatami użytymi do pochówku Jezusa, ${ }^{95}$ fakt obecności miecza przy rajskich cherubach $(\operatorname{Rdz} 3,24)$ $\mathrm{z}$ ich brakiem w przypadku Janowych aniołów (J 20,12). ${ }^{96}$ Do powyższych, nie do końca przekonujących, powiązań zaliczyć można także

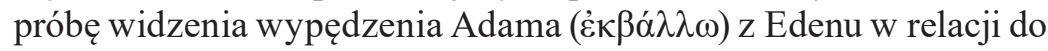

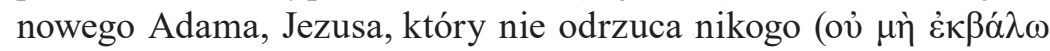
है $\xi \omega)(\mathrm{J} 6,37)$.

$$
* * *
$$

Obecność wyraźnych aluzji przy jednoczesnym braku oznaczonych cytatów z Rdz 1-3 w Ewangelii Janowej wskazuje, że temat stworzenia funkcjonuje bardziej jako narracja niż jako tekst. ${ }^{97}$ Temat stworzenia obecny jest w sposób niezwykle wyraźny na początku (1,1-18) i na końcu narracji $(20,22)$ Janowej. Powyższe inclusio wskazuje

92 M. R o s i k, Interpretacja, s. 45-48.55-58.

93 Te n ż e, Discovering the Secrets, s. 89-90.

94 Te n ż e, Interpretacja, s. 60: ,W rajskim ogrodzie złamanie zakazu przyniosło człowiekowi śmierć. W przypadku Marii Magdaleny, posłuszeństwo nakazowi Jezusa otwiera na przyjęcie nowego życia wypływającego ze zmartwychwstania”.

95 Tamże, s. 59-60. Autor wyjaśnia (s. 60): „W raju pierwszy Adam utracił życie nieśmiertelne i dlatego Bóg okrył jego nagość, nie pozostawiając go całkowicie bezbronnym; teraz nowy Adam, Chrystus, powraca do życia, porzuca więc szaty pogrzebowe, które nie są już potrzebne, gdyż nie ma w nich ciała, które miałyby chronić".

${ }_{96}$ Tamże, s. 61: „Cheruby zagradzały mieczami wejście do raju, rozumianego jako miejsce przebywania Boga; aniołowie przed grobem Jezusa nie mają mieczy, gdyż droga ku Bogu znów jest otwarta".

${ }_{97}$ M.J.J. M e n k e n, Genesis, s. 83-84. 
na klucz tematyczny, w jakim należy czytać całą Ewangelię i całe dzieło Jezusa. Jednocześnie Jan zaczyna swą Ewangelię od aluzji do pierwszego zdania Tory i całej Biblii, sugerując swym odbiorcom, że Ewangelia staje się nową Torą, nową Biblią, lub przynajmniej częścią czy bardziej kontynuacją historii opowiedzianej w Biblii. Odwołanie do tematu stworzenia wskazuje przede wszystkim na ścisłą łączność między Jezusem i Ojcem Stworzycielem. Jezus postrzegany jest zatem przez Jana jako uczestnik procesu stworzenia właściwego samemu Bogu Stworzycielowi. Chrystus występuje zarówno w roli Boga Stworzyciela (Logos z J 1,1-18), jak i nowego Adama (ogrodnik z J 20,15). Status Jezusa, przez odwołanie się do tematu stworzenia, ukazany jest jako unikalny w całej historii zbawienia, nieporównywalny z innymi postaciami (jak chociażby Abraham, Mojżesz czy Jan Chrzciciel). Temat stworzenia obecny w Ewangelii Janowej wskazuje zatem na jedność historii zbawienia, która, rozpoczynając się w stworzeniu, za sprawą Logosu, ma swoje dopełnienie w ziemskiej misji tegoż samego Logosu, Jezusa Chrystusa (20,22). Bardziej subtelnie obecny jest w Janie temat Jezusa jako nowego Adama. W ujęciu Janowym Mesjasz, Stworzyciel i nowy Adam, kontynuuje, kończy czy też odnawia dzieło stworzenia. Dzieło to dokonało się w Jezusie i przez Jego posługę, ale jest głoszone i kontynuowane przez wspólnotę Jego uczniów, rozumianą jako odnowiona ludzkość (nowa Ewa). Czytając Janowe aluzje do Rdz 1-3 w kluczu dopełnienia czy odnowienia stworzenia, ewangelista definiuje wspólnotę uczniów Jezusa jako pełnię stworzenia (uzdrowioną ludzkość) i nowe stworzenie, które odzyskało możliwość trwania w obecności Boga utraconą przez grzech Adama i Ewy. W tej perspektywie Kościół jest społecznością, która powróciła do utraconego Ogrodu Eden. Posługa tegoż Kościoła, nowej ludzkości, skierowana jest do każdego człowieka, stworzonego na obraz Boga i oczekującego objawienia stwórczej światłości świata. 
Słowa kluczowe: Ewangelia Janowa, stworzenie, ST w NT, intertekstualność Keywords: The Gospel of John, creation, the NT use of the OT, intertextuality

\section{The Theme of Creation in the Gospel of John}

\section{Summary}

The article surveys recent scholarship on the use of creation imagery in the Gospel of John, with the aim of presenting rather exhaustive register of possible references. Both the obvious and the less clear-cut allusions to Gen 1-3 are discussed, the main focus being to accumulate and assess evidence (for or against) all the apparent references to creation imagery. Included in this examination are several unconvincing and even far-fetched proposals advanced by some modern scholars, in order to give the fullest possible picture of current discourse on these issues. After discussing the creation theme in the Prologue (1:1-18), the article explores the presence of creation imagery in the Book of Signs (1:19-12:50) and the Book of Glory (13:1-21:25). 